\title{
PENERAPAN TEORI NASKH TERHADAP AYAT-AYAT JIHĀD (Studi Komparatif Antara Jalāl al-Dīn al-Suyūti dan Mahmūd Muhammad Taha )
}

\author{
Mokhamad Ali Ridlo
}

Email: alydahrie19@gmail.com

\author{
Abdul Ghofur \\ STAI Al Anwar \\ Gondanrojo-Kalipang Sarang Rembang \\ Email: AbdulGhofur@yahoo.com
}

\begin{abstract}
Abstrak
Pembacaan akan teori naskh kembali menjadi dilematis, ketika para pembaharu Islam seperti Taha mencoba merekontruksi konsep konvensional yang digagas al-Suyūti. Usaha tersebut sangat mungkin didasarkan atas asumsi teori naskh konvensional tidak lagi mampu melahirkan hukum Islam yang relevan dengan konteks budaya kontemporer saat ini. Bukan tidak mungkin, teori naskh mampu mempengaruhi cara berfikir umat Islam, terlebih bagi pihak yang memahami jihād sebagai gerakan ofensif. Kajian ini mencoba mengkomparasikan teori naskh yang diusung oleh al- Suyūți dan Țaha dan kemudian menjadikan format baru, dengan mengambil keunggulan dan meligitimasi kekurangannya. Selanjutnya, diterapkan terhadap ayat-ayat jihād. Melalui bingkai pemahaman terhadap fase diwajibkan jihād, kajian asbāb al-nuzūl serta teori-teori dalam studi al-Qur'an akan menghasilkan pemahaman yang tidak setimpang dan lebih komprehensif terkhusus dalam konteks jihād.
\end{abstract}

Key words: naskh, al-Suyūti, Taha, jihād.

\section{A. Pendahuluan}

Kajian al-Qur'an selalu mengalami perkembangan yang cukup dinamis, seiring dengan perkembangan kondisi sosial-budaya dan peradaban manusia. Hal ini terbukti dengan munculnya beberapa karya tafsir, mulai dari klasik sampai kontemporer dengan berbagai corak, metode dan pendekatan yang digunakan. ${ }^{1}$ Namun, ibarat samudra yang luas dan dalam al-Qur'an tidak akan pernah mengalami kekeringan, meskipun telah, sedang dan akan terus dikaji dari berbagai segi dan metodologi. Oleh sebab itu, semua kajian al-Qur'an saling bersinggungan, berhubungan serta mendukung dan memperkaya khazanah ke-Islam-an. ${ }^{2}$

\footnotetext{
${ }^{1}$ Abdul Mustaqim, "Epistimologi Tafsir Kontemporer, Studi Komparatif antara Fazlur Rahman dan Muhammad Syahrur" (Disertasi : UIN Sunan Kalijaga Jogjakarta, 2007), 1.

${ }^{2}$ M. Quraish Shihab, Kaidah Tafsir, Syarat, Ketentuan dan Aturan yang Patut Anda Ketahui Dalam Memahami Ayat-Ayat al-Qur'an, ( Tanggerang : Lentera Hati, 2013), 6.
} 
Keberagaman kajian al-Qur'an didasari karena sebagian orang secara apriori menerima postulat bahwa al-Qur'an șālihu likulli zamān wa makān. ${ }^{3}$ Tidak cukup apabila alQur'an hanya dibaca sebagai rutinitas sehari-hari tanpa memahami maksud, mengungkap isi serta mengetahui prinsip-prinsip yang terkandung di dalamnya. ${ }^{4}$ Tentu hal ini bukan persoalan mudah, mengingat al-Qur'an merupakan kitab suci yang mengandung kosa kata yang tidak mudah untuk dimengerti, misalnya beberapa kosa kata yang secara literal dianggap bertentangan. Dibutuhkan sebuah penafsiran agar mendapatkan pemahaman benar dan sesuai dengan zamannya. ${ }^{5}$ Menafsirkan kandungan al-Qur'an tidak cukup hanya kemahiran dalam berbahasa Arab, melainkan perlu menguasai secara komperhensif teori-teori yang berhubungan dengan studi al-Qur'an. ${ }^{6}$

Dalam studi al-Qur'an, salah satu teori dasar yang populer dikalangan para ulama adalah teori naskh (abrogation theory). Hampir semua kitab ulūm al-Qur'an maupun uṣul alfiqh, baik klasik maupun kontemporer selalu menyebutkan bab naskh. ${ }^{7}$ Tidak hanya diperbincangkan, keberadaannya dianggap begitu penting untuk mempermudah dalam memahami dan menafsirkan hukum-hukum al-Qur'an. ${ }^{8}$

Diskursus mengenai ada dan tidaknya naskh dalam al-Qur'an sudah terjadi sejak lama. Apabila dibenarkan bahwa naskh benar-banar ada, apakah hal itu tidak berarti Allah bersikap inkonsisten dalam menentukan suatu ketentuan hukum. Di sisi lain, jika dikatakan bahwa tidak ada naskh, lalu mengapa dalam al-Qur'an terdapat beberapa ayat yang mengisyaratkan $n a s k h$ ? Bahkan terdapat ayat yang secara tegas menyebut kata naskh, sebagaimana firman Allah Subhānahu wa Ta'āla:

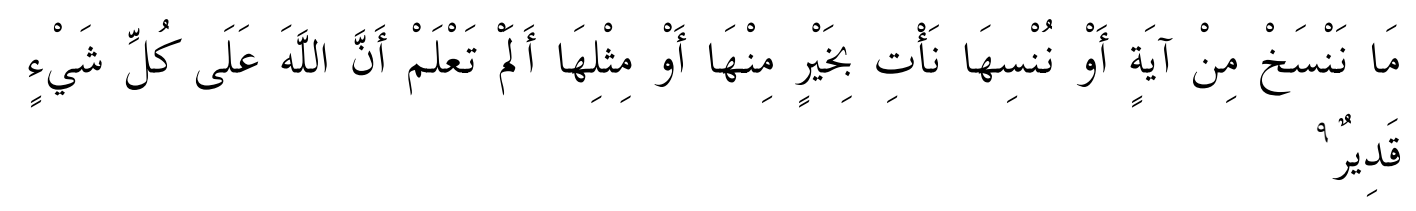

\footnotetext{
${ }^{3}$ Munzir Hitami, Pengantar Studi al-Qur'an; Teori dan Pendekatan, ( Yogyakarta : LKIS, 2012 ), 2.

${ }^{4}$ M. Nurdin Zuhdi, “Tipologi Tafsir al-Qur'an Madzhab Indonesia”, (Tesis di UIN Sunan Kalijaga Yogyakarta, 2011), 2.

${ }^{5}$ Zainul Mun'im, “Teori Nasīkh Mansūkh al-Qur'an Sebagai Pembaharuan Hukum Islam”, ( Skripsi di UIN Sunan Kalijaga, Yogyakarta, 2013 ), 2.

${ }^{6}$ Lihat syarat-syarat mufasir, Manna' al-Qaț̣ān, Mabāhits Fī Ulūm al-Quran, (ttp : Maktabah Wahbah, tp), 322.

${ }^{7}$ Abdul Mustaqim, Penelitian al-Qur'an dan Tafsir, ( Yogyakarta : Idea Press, 2014 ), 43.

${ }^{8}$ Jalāl al-Din al-Suyūti, Al-Itqān Fi ulūm al-Quran, ( Bairut : Dar al-Fikr, 2008 ) 2 : 326.

${ }^{9}$ Al-Qur'an, $2: 106$.
} 
Penerapan Teori Naskh terhadap Ayat-Ayat Jihād ..... Mokhamad Ali Ridlo \& Abdul Ghofur

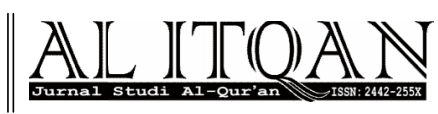

Ayat mana saja yang Kami nasakh-kan, atau Kami jadikan (manusia) lupa kepadanya, Kami datangkan yang lebih baik atau yang sebanding dengannya. Tidakkah kamu mengetahui bahwa sesungguhnya Allah Maha Kuasa atas segala sesuatu.

Ketika terdapat kesan kontradiktif antar ayat-ayat al-Qur'an dan dianggap tidak dapat dikompromikan, para ulama menjadikan teori naskh sebagai langkah utama untuk menyelesaikan problem tersebut. Sebagai contoh, ayat tentang wasiat di-naskh ayat yang menjelaskan warisan.

Kemudian, perbedaan makna naskh yang terjadi di antara sekte Sunni dan Mu'tazilah pada hakikatnya memilki subtansi sama yakni terdapat ayat al-Qur'an yang isinya tidak berlaku lagi dikarenakan ada ayat belakangan yang menyatakan lain. Ulama Sunni menyebutnya nasīkh dan Mu'tazilah mengistilahkan dengan takhsīs. Apabila terdapat pendapat yang menyatakan tidak berlakunya naskh secara mutlak dalam al-Qur'an, maka bisa disebut pendapat yang syad (aneh). ${ }^{10}$

Pada tahap selanjutnya perbedaan naskh juga muncul karena metodologinya. Dewasa ini, beberapa sarjana muslim kontemporer melakukan rekontruksi naskh konvensional yang diprakarsai oleh beberapa ulama klasik seperti Jalāl al-Din al-Suyūti dalam kitab al-Itqān, dan al-Zarkasyi dalam al-Burhān fí Ulūm al-Quran. ${ }^{11}$ Para sarjana kontemporer menganggap konsep konvensional tidak mencerminkan universalitas al-Qur'an. ${ }^{12}$ Mereka mencoba menelaah kembali konsep naskh dengan menitik beratkan pada aspek kemaslahatan hukum dan relevansinya terhadap perkembangan zaman. Di antara mereka yaitu Mahmūd Muhammad Taha dan muridnya, Abdullah Ahmed al-Na'im ${ }^{13}$

Sebagai representasi perwakilan mufasir era klasik dan kontemporer penulis mengambil sampel tokoh Jalāl al-Din al-Suyūti dan Mahmūd Muhammad Țaha. Kedua tokoh tersebut dianggap lebih aplikatif dalam merumuskan metodologi. Epistimologi yang dibangun keduanya hampir mirip, yakni memiliki implikasi-implikasi yang cukup signifikan dan sangat

\footnotetext{
${ }^{10}$ Ibnu al-Jauzy, Nawāsikh al-Qur'an, (Madinah : Maktabah al-‘Arabiyah al-Su’udiyah, 1984 ), 17

${ }^{11}$ Zainul Mun'im, “Teori Nasīkh Mansūkh..., 21.

${ }^{12}$ Yang dimaksud dengan universalitas al-Qur'an di sini bukan berarti al-Qur'an hanya memiliki satu baku hukum yang sama untuk segala masa, melainkan al-Qur'an menyediakan berbagai hukum yang dapat diterapkan sesuai dengan konteks masanya. Lihat Muahmmad Syahrur, Prinsip dan Dasar Hermeneutika Hukum Islam Kontemporer, terj. Sahiron Syamsuddin, (Yogyakarta : ELSAQ Press, 2007 ), 52.

${ }^{13}$ Gagasan-gagasan mereka tentang rekontruksi teori nasīkh mansūkh dapat dilihat dalam literatur sebagai berikut : al-Risālah al-Tsaniyah fi al-Islām karya Mahmūd Muhamad Țaha, Toward an Islamic Reformation karya Abdullah Ahmed al-Na'im ( diterjemah Ahmad Suaedy dalam Dekontruksi Syariah ).
} 
relevan bagi perkembangan khazanah ke-Islam-an. Dan berangkat dari semangat yang sama pula, yaitu ingin menjadikan al-Qur'an sebagai landasan moral bagi umat manusia dalam mengemban amanah Tuhan, sekaligus membuktikan bahwa dia selalu șālihu li kulli zamān wa makān. Meskipun demikian, dalam konteks ini konsep yang ditawarkan keduanya tidaklah sama.

Al-Suyuti masih terlihat apresiatif terhadap konsep tradisionalisme, yaitu menghilangkan hukum lama dengan hukum baru, ataupun mengganti hukum lama dengan hukum baru. ${ }^{14}$ Berbeda dengan teori naskh al-Suyūti, Mahmūd Muhammad Ṭaha lebih cenderung mengartikan naskh sebagai penundaan hukum. Gagasan Țaha ini tercermin melalui tafsirannya terhadap surat al-Baqarah ayat $106 .^{15}$

Ayat yang kami naskh (menghapus hukum suatu ayat) atau yang kami tunda pelaksanaannya (aw nansakha), maka kami gantikan dengan ayat yang lebih dekat dengan pemahaman manusia atau memulihkan berlakunya ayat itu pada saat yang tepat. ${ }^{16}$

Naskh dengan pengertian ini dalam arti menghapuskan sementara waktu, dan ketika sampai waktunya hukum itu akan berlaku kembali.

Adanya persamaan dan perbedaan tersebut tentu memiliki implikasi dan konsekuensi tersendiri dalam penafisran al-Qur'an. Sebagai contoh misalnya jika konsep naskh diterapkan dalam ayat-ayat jihad. Melalui teori naskh al-Suyūti akan memberikan kesan bahwa ayat-ayat jihad telah menghapus ayat-ayat yang mengajarkan toleransi, memberi maaf, bersikap sabar dan yang semakna dengan itu. Sementara dengan teori Taha justru sebaliknya, ayat-ayat jihad dihapus dengan ayat-ayat toleransi.

Latar belakang pemilihan ayat jihad didasari karena saat ini arti jihad telah mengalami perluasan makna, terdapat beberapa oknum yang memberikan makna jihad tidak lagi bersungguh-sungguh, membela diri atas serangan musuh. Selain itu, Entah karena pemahaman parsial terhadap ayat al-Qur'an atau terpengaruh akan konsep naskh, yang jelas sebagian teroris mengatas namakan ayat-ayat jihad untuk melegitimasi apa yang mereka lakukan. ${ }^{17}$ Dengan kesalah pahaman dan stigma buruk terhadap jihad, tidak sedikit kaum muslim kerepotan dan disusahkan untuk menjelaskan konsep dan

\footnotetext{
${ }^{14}$ Jalāl al-Dīn al-Suyūti, Al-Itqā̄ Fi ulūm al-Quran ..., 326.

${ }^{15}$ Ayat ini dianggap sebagai dasar penetapan teori naskh.

${ }^{16}$ Mahmūd Țaha, Risalah al-Tsaniyah fi al-Islām, ( ttp : tnp, tth ), 10.

${ }^{17}$ Ahmad Baidlowi, Mengenal Thabathaba'i dan Kontroversi Nasīkh Mansūkh, (Bandung : Nuansa, 2005 ), 10.
} 
Penerapan Teori Naskh terhadap Ayat-Ayat Jihād ..... Mokhamad Ali Ridlo \& Abdul Ghofur

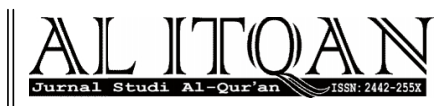

sejarah jihad dengan tepat setelah ia mengalami reduksi dan penyimpangan makna. Dengan demikian, bukan tidak mungkin konsep naskh bisa sangat mempengaruhi cara berfikir umat Islam, bukan saja mengenai hubungan antar agama, melainkan juga dalam berbagai bidang kehidupan lain. ${ }^{18}$

Persoalan yang muncul kemudian adalah mungkinkah mencoba memadukan dua model teori naskh menjadi format baru dalam metodologi tafsir, dengan memilih keunggulan dan mengeliminir kekurangan dari kedua tokoh tersebut. Hal ini mengingat keduanya memiliki kelebihan dan kekurangan, antara lain konsep yang ditawarkan alSuyūti selain menghilangkan nilai validitas al-Qur'an yang kekal dan abadi, juga menghasilkan produk yang kurang relevan terhadap perkembangan sekarang. Taha memberikan konsep tanpa batas, sehingga menjadikan orang-orang yang sejalan dengan pemikirannya akan selalu berfikir liar. Tanpa melihat kapan dan dimana sebenarnya pemikiran itu bisa diterapkan.

Dengan menggunakan model penelitian analisis komparatif, tulisan ini akan menjelaskan teori naskh baik menurut Jalāl al-Dīn al-Suyūti maupun Muhammad Mahmūd Țaha. Kemudian membandingkan kedua teori tersebut dan diterapkan dalam ayat-ayat jihad.

\section{B. Sekilas tentang Jalāl al-Dīn al-Suyūti dan Muhammad Mahmūd Ṭaha}

Jalāl al-Dīn al-Suyūti memiliki nama lengkap Abdu al-Rahman bin al-Kamal bin Abu Bakar bin Muhammad bin Sabiq al-Suyūti. Dilahirkan di Șuyuṭ pada bulan Rajab tahun 849 $\mathrm{H}$, dan menjadi seorang piatu sejak ibunya wafat sesaat dia dilahirkan. Ketika usianya beranjak lima tahun ayahnya meninggal dunia.

Al-Dzahabi menyebutkan bahwa al-Suyūti merupakan orang paling 'alim di masanya. Segala disiplin ilmu dikuasai, baik yang berkaitan dengan al-Qur'an, Hadis, rijāl dan gharib al-Hadis. ${ }^{19}$ Dalam sebuah kesempatan al-Suyuthi pernah mengungkapkan bahwa dia menghapal 200.000 Hadis, bahkan dia pernah mengatakan "Sekira saya menemukan hadis lain, maka niscaya saya akan menghapalnya". ${ }^{20}$ Selain menghafal al-Qur'an dan hadis, al-

\footnotetext{
18 Azyumardi Azra, Konflik Baru Antar Peradaban: Globalisasi, Radikalisme \& Pluralitas, (Jakarta: Rajagrafindo Perkasa, 2002), 81.

${ }^{19}$ Muhammad Husain Al-Dzahabi, al-Tafsìr Wa al-Mufassirūn, (ttp: Makatabah Wahbah, t.th), 180.

20 Ibid, 180 .
} 
Suyūti juga mampu menghafal berbagai kitab yang berorentasi ilmu pengetahuan, seperti kitab Umdah al-Ahkam, Alfiyyah Ibnu Mālik, Minhaj al-Thalibin. ${ }^{21}$

Dalam menimba ilmu pengetahuan, al-Suyūti selalu berpindah dari satu negara ke negara lain, seperti Syam (Syiria), Hijaz, Yaman, India, dan Maroko. ${ }^{22}$ Pada masa ini, dia disibukan mengarang berbagai karya tulis. Tidak hanya itu, al-Suyūti juga berprofesi sebagai tenaga pengajar di Madrasah al-Syaikhuniqah selama 12 tahun dan menjabat sebagai mufti pada waktu yang lama. ${ }^{23}$

Setelah al-Suyūṭi berusia 60 tahun yakni sekitar tahun $909 \mathrm{H}$, dia mulai fokus beribadah dan mendekatkan diri kepada Allah, berpaling dari dunia dan segala kemewahan, bahkan dia sempat tidak mengenal orang-orang sekitar. Selain itu, dia juga meninggalkan profesinya sebagai mufti, mengajar, sekaligus mengurangi kegiatan menulis.

Jalāl al-Dīn al-Suyūti wafat pada malam Jum'at tanggal 19 Jumadil Awal 911 H/ 1505 M, genap berusia 61 tahun 10 bulan 18 hari. Jasad al-Suyūti dimakamkan di Husy Qushun di luar Bab Qarafah, Kairo. ${ }^{24}$

Tidak berbeda dengan Jalāl al-Dīn al-Suyūti, diusia yang masih belita Muhammad Mahmūd Ṭaha ditinggal kedua orang tuanya. Data yang ditemukan menginformasikan Mahmūd Muhammad Țaha dilahirkan antara tahun 1909 atau 1911 di Rufa'ah, kota kecil di tepi timur Blue Nile, Sudan Pusat. ${ }^{25}$

Dalam pendidikan, sekolah dasar hingga menengah ditempuh di tanah kelahiran, Rufa'ah. Pada tahun 1932 Țaha terdafar sebagai mahasiswa Gordon Memorial College ${ }^{26}$ fakultas Teknik dan berhasil diselesaikan tahun $1932 .{ }^{27}$ Selepas menyelesaikan studinya, kurang lebih empat tahun dia menjadi pegawai jawatan kereta api Sudan. Pada tahun 1940 dia berhenti dan mendirikan lembaga pendidikan. ${ }^{28}$

\footnotetext{
${ }^{21}$ Abi al-Falah Abdu al-Hayy Ibnu Ahmad bin Muhammad bin al-'Imād, Syadarat al-Dzahab, (ttp : tnp, tth), 8 : 52.

${ }^{22}$ Abi Falah, Ibid,

${ }^{23}$ Dewan Redaksi, Ensiklopedi Islam, (Jakarta : Ichtiar Baru, 1994) 4 : 324.

${ }^{24}$ Jalāl al-Dīn al-Suyūti, Al-Itqān Fi ulūm al-Quran, 55.

${ }^{25}$ P.J Bearman, dkk, The Encyclopedia of Islam, (Leiden : Brill, 2000), 96.

${ }^{26}$ Pada tahun 1936 menjadi University of Khartoum

${ }^{27}$ Mahmūd Muhammad Taha, Syari'ah Demokratik, terj. Nur Rachman, ( Surabaya : elSAD), 27

${ }^{28}$ P.J Bearman, dkk, The Encyclopedia of Islam, 96.
} 
Penerapan Teori Naskh terhadap Ayat-Ayat Jihād ..... Mokhamad Ali Ridlo \& Abdul Ghofur

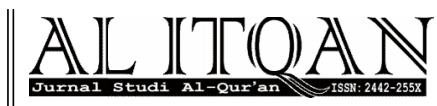

Disamping aktif di dunia pendidikan, Țaha juga aktif dalam pergerakan nasional Sudan. Partisipasinya dalam pergerakan tersebut dimulai pada akhir tahun 1930, karena merasa tidak puas terhadap pola pendidikan yang diterapkan pada saat itu. Awal kemunculan pergerakan ini, dia memberikan kecaman dan kritikan pedas kepada pelajar Sudan yang menyerahkan keahlian dan kemampuan kepada pemimpin agama seketarian tradisionalis. ${ }^{29}$ Disamping itu, Țaha juga tidak senang dengan partai politik, sebab hanya cenderung menerima perlindungan dari penguasa kolonial, dari pada menyelaraskan komitmen dan garis perjuangan bagi kemerdekaan Sudan dan terbentuknya sebuah Negara Sudan merdeka yang berdaulat. ${ }^{30}$

Tahun 1945 Mahmūd Muhammad Țaha dan beberapa orang sahabat yang sepaham dengan pola pikirnya mendirikan al-Hizb al-Jumhuri (Partai Republik) yang menjadi sarana untuk memperjuangkan ideologinya demi kemajuan masyrakat. Namun, setelah Ja'far Numeiri menjadi presiden melalui kudeta militer tahun 1969 M seluruh partai di Sudan dibubarkan. Kemudian Partai Republik mengalami tranformasi menjadi Persaudaraan Kaum Republik (Republican Brothers). Pada awal pemerintahan Numeiri, Țaha masih rajin ceramah di tempat-tempat umum dan menulis berbagai pendangannya di surat kabar. Tahun 1973 M kegiatan menulis, mengajar serta mendiskusikan pemikiran Țaha mulai diintesifkan, sebab rezim Numeiri mencekal sekaligus melarang Taha memberikan ceramah dan mengaktualisasikan pemikirannya secara terbuka.

Tahun 1977 M. Mahmūd Muhammad Țaha ditangkap dan ditahan selama satu bulan tanpa tuduhan yang jelas. Kemudian pada tanggal 13 Mei 1983 M, sebelum progam Islamisasi dicanangkan oleh pemerintah, Țaha dan sebagian pengikutnya ditahan tanpa pemeriksaan resmi, karena membuat selebaran yang mengkritik kebijakan pemerintah dalam menangani masalah yang merugikan non-muslim. Kemudian dibebaskan pada pada tanggal 19 Desember 1984. Dan ditangkap kembali pada tanggal 5 Januari 1985 M atas dasar tuduhan berusaha mengubah konstitusi, menghasut dan mendorong oposisi secara inkonstitusional terhadap pemerintah.

Selanjutnya, tanggal 8 Januari 1985 Țaha dan keempat sahabatnya mendapatkan putusan hukuman mati oleh dewan hakim dengan catatan mereka dapat terbebas apabila

\footnotetext{
${ }^{29}$ Mereka hanya menyerukan dukungan luas dari masyarakat Sudan.

${ }^{30}$ Muhammad Mahmūd Ṭaha, Risalah al-Tsaniyah, 27-28.
} 
mereka mau bertaubat dan menarik kembali pemikiran mereka. Tepatnya tanggal 15 Januari 1985, pengadilan tingkat banding Sudan kembali mengumumkan hukuman mati kepada Țaha. Kemudian presiden Numeiri mempertegas keputusan pengadilan itu pada tanggal 17 Januari 1985, dengan memberi kesempatan empat terdakwa lain untuk bertaubat dan mengakui kesalahan. Sementara eksekusi Țaha dilaksanakan pada hari Jum'at tanggal 18 Januari 1985 dan dipimpin langsung oleh presiden Numeiri. ${ }^{31}$

\section{Konsep Nasīkh menurut al-Suyūti dan Țaha}

Dalam merespon ada dan tidaknya naskh dalam al-Qur'an, baik Jalāl al-Dīn al-Suyūti maupun TTaha sepakat terdapat naskh dalam al-Qur'an. Dengan mengutip peryataan para ulama, al-Suyuti mengatakan seseorang tidak boleh menafsirkan Al-Qur'an kecuali dia mengetahui tentang nasikh dan mansukh. ${ }^{32}$

Menurut al-Suyuti, naskh merupakan hukum Allah yang dikhususkan untuk umat ini, karena terdapat beberapa hikmah di dalamnya, seperti mempermudah pemahaman terhadap al-Qur'an (al-taysir). ${ }^{33}$ Naskh hanya terjadi pada ayat yang berupa perintah dan larangan, meskipun hanya berbentuk berita. Berita yang tidak mememilki kandungan tuntutan (thalab) tidak dikategorikan naskh. Sebagai contoh berita tentang janji dan ancaman. al-Suyūti mengatakan "Jika engkau mengetahui perihal ini, pasti kalian akan mengetahui kerusakan individu yang memasukkan ke dalam kategori naskh ayat-ayat yang berupa berita, janji dan ancaman". 34

Dalam menentukan ayat naskh al-Suyūti sangat selektif. Terdapat beberapa ketentuan yang harus dipenuhi agar suatu ayat dapat digolongkan nasīkh dan mansūkh. Dengan mengutip ucapan Ibnu al-Hașār, al-Suyūti mengatakan "Naskh hanya bisa terjadi melalui riwayat șahih dari Nabi Șalla Allah 'Alayhi wa Sallam atau ucapan sahabat, ayat ini di-naskh dengan ayat ini. Naksh dapat berlaku ketika terjadi kontradiksi diantara dalil qat'i, sekaligus diketahui asbāb al-nuzulnya mana ayat yang turun dahulu dan kemudian. Dengan demikian perkataan maupun ijtihad mayoritas mufasir tidak dapat dijadikan landasan, kecuali apabila melalui riwayat șahih sekaligus diketahui asbāb al-nuzul-nya, sebab makna yang terkandung

\footnotetext{
${ }^{31}$ Mahmūd Muhammad Țaha, Risalah al-Tsaniyat, 47.

${ }^{32}$ Jalāl al-Dīn al-Suyūti, Al-Itqān Fi ulūm al-Quran, 2 : 326.

33 Ibid, 326.

34 Ibid.,
} 
Penerapan Teori Naskh terhadap Ayat-Ayat Jihād ..... Mokhamad Ali Ridlo \& Abdul Ghofur

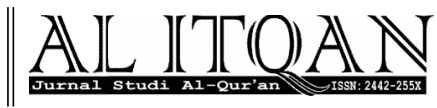

dalam naskh sendiri yaitu menghilangkan suatu hukum dan menetapkan hukum lain di era Nabi Muhammad Șalla Allah 'Alayhi wa Sallam. ${ }^{35}$

Sementara Țaha memandang perlu sebuah reformasi syariah, karena formulasi syariah yang ada dinilai tidak lagi memadai dan relevan untuk mengakomodasi tuntutan kehidupan modern. Pada dasarnya, konsep Taha tentang naskh hampir mirip dengan yang dikenalkan para ulama, yakni sebagai teknik megkompromikan ayat-ayat yang secara subtansial dianggap bertentangan, dengan cara menghapuskan atau meneguhkan salah satunya. Perbedaan Ṭaha dengan mereka terletak pada proses dan akibatnya. Konsep naskh yang ditawarkan para ulama pada umumnya yaitu penghapusan dan meneguhkan ayat yang dahulu turun (mansükh) oleh ayat yang turun kemudian (nasīkh), selanjutnya ayat yang mansūkh tidak dipergunakan lagi. ${ }^{36}$

Sementara Taha menilai bahwa naskh bersifat tentatif sesuai dengan kebutuhan. Dalam arti, ayat mana yang dibutuhkan pada masa tertentu maka ayat itulah yang diberlakukan, sedangkan ayat yang tidak diperlukan ${ }^{37}$ dihapuskan. Sehinga naskh menurut Țaha menghapus atau meneguhkan ayat yang datang kemudian oleh ayat terdahulu, atau bahkan sebaliknya apabila memang kondisi modern menghendakinya. Ayat yang sudah dinyatakan mansūkh apabila diperlukan dapat digunakan lagi pada kesempatan lain.

Menurut Taha, naskh merupakan proses evolusi syari'ah yakni perpindahan dari suatu teks ke teks lain yang relevan dan kontekstual. Dari teks yang pantas mengatur kehidupan abad ketujuh dan telah ditetapkan, kepada teks yang pada waktu itu terlalu maju, oleh sebab itu dibatalkan. Dalam menyikapi firman Allah Subhānahu wa Ta'āla surat al-Baqarah ayat 106, Țaha memiliki sudut pandang yang kontroversial. Menurutnya "kami datangkan ayat yang lebih baik" berarti membatalkan atau mencabut, sedangkan kalimat "atau menundanya" berarti menunda pelaksankan atau penerapannya. Kalimat "kami datangkan yang lebih baik" Țaha mengartikannya "mendatangkan ayat yang lebih dekat dengan pemahaman masyarakat dan lebih sesuai dengan mereka dari pada ayat yang ditunda”. Sementara maksud kalimat "atau ayat yang sebanding dengannya" berarti mengembalikan ayat yang sama ketika waktu memungkinkan untuk menerapkan kembali. ${ }^{38}$

\footnotetext{
${ }^{35}$ Jalāl al-Dīn al-Suyūti, Ibid, 331.

36 Ibid.,

${ }^{37}$ Karena dianggap tidak relevan dengan perkembangan kontemporer

38 Ibid, 110.
} 
Sehingga dapat dipahami konsep naskh yang ditawarkan Taha berbeda dengan teori naskh yang digagas al-Suyūti (lebih memperhatikan waktu turunnya ayat). Dalam konsep naskh al-Suyūti pemberlakuan ayat dilihat mana yang datang kemudian. Sehingga ayat-ayat Madani yang datang belakangan secara otomatis me-nasakh ayat Makky yang datang lebih dahulu. Sehingga ayat yang berlaku secara fungsional adalah ayat Madani, sementara ayat Makky tidak berlaku.

Berbeda dengan paradigma konvensional, naskh perspektif Țaha lebih menekankan hakikat dan kondisi pewahyuan. Pe-naskh-an dan pemberlakuan ayat tergantung tuntutan, kebutuhan dan kemaslahatan. Ketika terdapat kebutuhan menghendaki pemberlakuan ayat Makkah, maka ayat tersebut diberlakukan, begitu pula sebaliknya. Dengan demikian, bagi Taha pemberlakuan ayat-ayat sangat kondisional dan kontekstual. Naskh menurut Taha tidak bersifat final dan permanen.

Persoalannya kemudian adalah bagaimana menentukan ayat Makki dan Madani. Dalam hal ini, Taha sendiri menghadapi masalah, pengelompokkan ayat periode Makkah dan Madinah terdapat tumpang tindih. Menurut Țaha penyebutan tempat pewahyuan itu tidak signifikan. Pengelompokan Makki dan Madani merupakan istilah untuk menunjukkan perbedaan dalam konteks dan audiens wahyu. Terdapat sebagian ayat Makki yang substansinya merupakan ayat Madani, demikian sebaliknya. Karena itu, ayat-ayat bersubtansi toleran dan demokratis dianggap sebagai ayat Makkah, dan ayat yang berlawanan atau tidak sejalan dengan semangat itu dikelompokkan sebagai ayat Madani. ${ }^{39}$

Meskipun al-Suyūti dan Țaha sama-sama menggunkan konsep naskh, namun konsekuensi hukum yang dihasilkan berbeda bahkan mungkin berlawanan satu sama lain. Kerja naskh yang dikembangkan Jalāl al-Dīn al-Suyūti melahirkan syari'ah yang berlaku hingga saat ini (syari'ah traditional). Sementara kerja naskh yang digagas Taha dapat melahirkan syari'ah yang temporer namun sesuai kebutuhan modern (syari'ah modern).

\footnotetext{
${ }^{39}$ Muhammad Mahmūd Ṭaha, Risalah al-Tsaniyat, 118.
} 
Penerapan Teori Naskh terhadap Ayat-Ayat Jihād .....

Tabel 1

Konsep Naskh :

Prespektif Jalāl al-Dīn al-Suyūti dan Mahmūd Muhammad Ṭaha

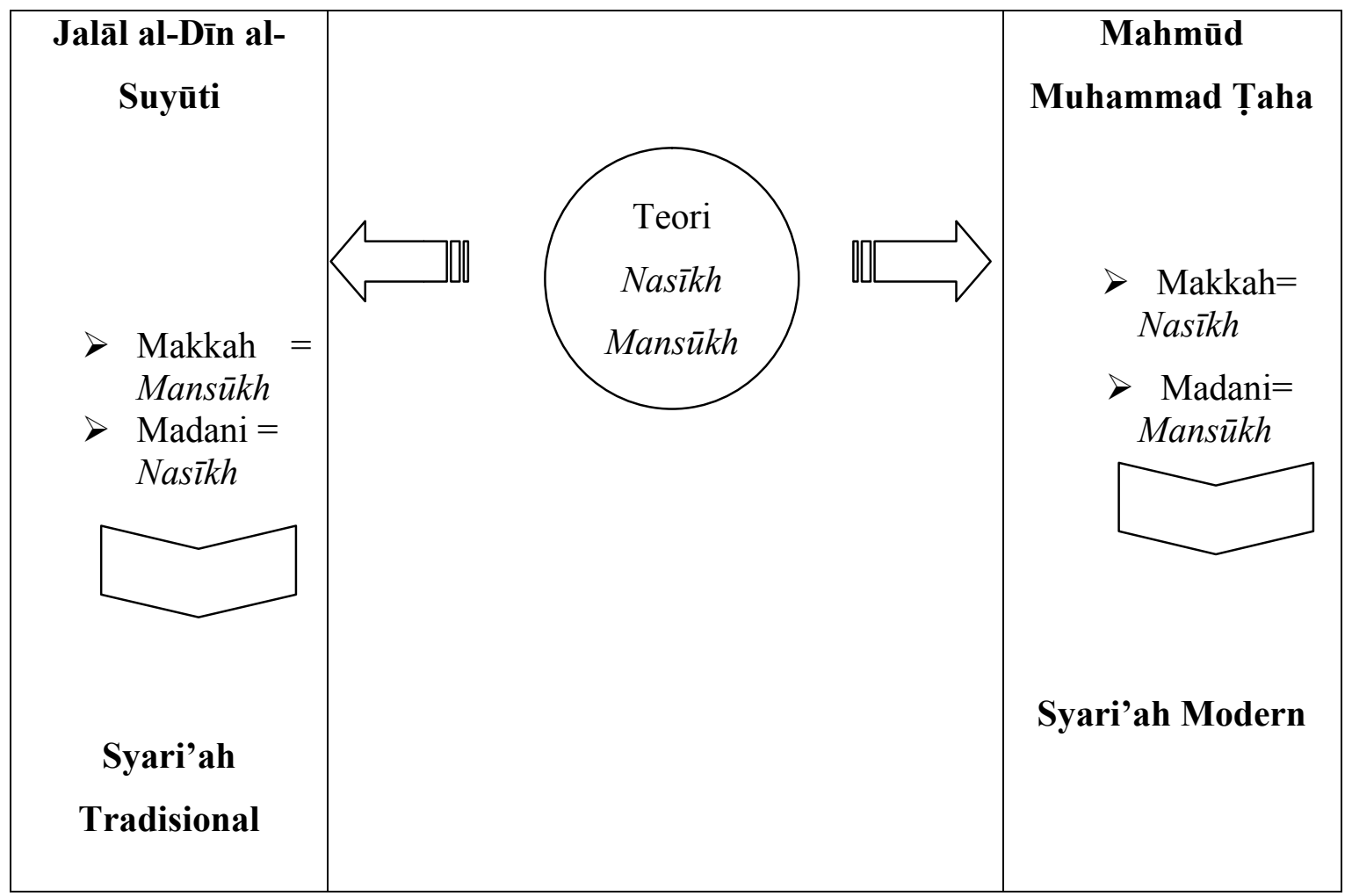

Dari gambar di atas, tampak bahwa konsep naskh yang ditawarkan Țaha memutar balik kerja naskh al-Suyūti yang lazim dilakukan oleh para ahli hukum Islam. Dengan kata lain, naskh versi Taha adalah naskh terbalik atau kebalikan naskh al-Suyūti. Perbedaan satu sama lain terletak pada objek naskh-nya. Menurut al-Suyūti ayat Makki di-naskh ayat Madani, sementara Țaha sebaliknya ayat Madani di-naskh ayat Makkah.

Kendati perbedaan itu sangat sederhana, akan tetapi hasil dan implikasi yang ditimbulkan sangat jauh berbeda. Sebagai contoh, apabila naskh al-Suyūti dapat menghasilkan hukum mewajibkan jihad, maka naskh Țaha justru sebaliknya, mengharuskan hidup berdampingan dengan penuh toleransi dan persahabatan. Naskh al-Suyūti menimbulkan diskriminasi hukum dan hak-hak sosial politik antara kaum laki-laki dan perempuan, muslim dan non-muslim. Sementara naskh Ṭaha menghapuskan diskriminasi tersebut.

Meskipun demikian, baik teori naskh al-Suyūti dan Țaha, sama-sama memiliki kelebihan dan kekurangan. Konsep yang ditawarkan oleh al-Suyūti selain dianggap mengurangi spirit Al-Qur'an șālihu likulli zamān wa makān, juga menghasilkan produk hukum yang kurang relevan terhadap perkembangan sekarang. Sementara Taha memberikan 


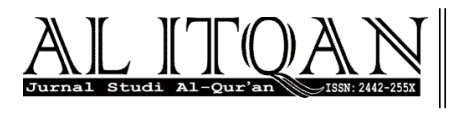

Penerapan Teori Naskh terhadap Ayat-Ayat Jihād .....

Mokhamad Ali Ridlo \& Abdul Ghofur

konsep tanpa batas, sehingga menjadikan orang-orang yang sejalan dengan pemikirannya akan selalu berfikir liar. Tanpa melihat kapan dan dimana sebenarnya pemikiran itu bisa diterapkan. Lebih dari itu, kelebihan serta kekurangan teori kedua tokoh semakin nampak, ketika dilihat dari segi proses dan implikasinya. Teori al-Suyūti lebih mengedepankan riwayat șahih, sehingga bersifat final dan konklusif, sementara teori Ṭaha cukup berdasarkan ijtihad, selama kondisi membutuhkan maka ayat yang telah dikalim mansūkh dapat digunakan kembali (kontekstual). Melalui teori al-Suyūti akan banyak ayat al-Qur'an yang tidak lagi bisa digunakan (ghoiru muhkam), berbeda dengan teori Țaha, akan ditemukan ayat-ayat muhkam.

Table II

Kelebihan dan Kekurangan

Teori Naskh Jalāl al-Dīn al-Suyūti dan Mahmūd Muhammad Ṭaha

\begin{tabular}{|c|c|}
\hline Jalāl al-Dīn al-Suyūti & Mahmūd Muhammad Ṭaha \\
\hline $\begin{array}{c}\text { Sumber dari riwayat sohih (dari } \\
\text { Nabi Muhammad atau perkataan } \\
\text { sahabat) }\end{array}$ & $\begin{array}{c}\text { Sumber berdasarkan Ijtihad } \\
\text { (ra'yu) }\end{array}$ \\
\hline Bersifat final dan konklusif & $\begin{array}{c}\text { Bersifat relevan dan } \\
\text { kontekstual }\end{array}$ \\
\hline $\begin{array}{c}\text { Menjadikan sebagian ayat al- } \\
\text { Qur'an ghoiru muhkam (tidak bisa } \\
\text { digunakan) }\end{array}$ & $\begin{array}{c}\text { Menjadikan sebagian ayat al- } \\
\text { Qur'an muhkam (dapat } \\
\text { digunakan) }\end{array}$ \\
\hline $\begin{array}{c}\text { implikasinya Islam terkesan } \\
\text { menjadi agama yang inklusif }\end{array}$ & $\begin{array}{c}\text { implikasinya Islam terkesan } \\
\text { menjadi agama yang ekslusif }\end{array}$ \\
\hline
\end{tabular}

Dari table di atas, nampak sekali kelebihan dan kekurangan masing-masing teori naskh dari al-Suyūti dan Ṭaha. Menurut al-Suyūti, yang dapat menentukan ayat nasīkh dan mansūkh hanya para ulama yang tahu akan studi al-Qur'an khususnya dalam asbāb al-nuzūl, dan berdasar riwayat yang șahih dari Nabi Muhammad Șalla Allah 'Alayhi wa Sallam atau sahabat. Semetara Taha hanya mengedepankan ra'yu, sehingga siapa saja yang memiliki kecakapan dalam bahasa Arab atau lebih tepatnya dapat memahami al-Qur'an bisa menentukan ayat nasīkh dan mansūkh. Kemudian, teori al-Suyuti menjadikan sebagian ayat al-Qur'an tidak dapat difungsikan, sementara penawaran Ṭaha justru sebaliknya sebagian ayat al-Qur'an dapat kembali berfungsi. Perbedaan konsep yang ditawarkan berawal dari pemaknaan naskh itu sendiri. Dalam memahami surat al-Baqarah ayat 106 al-Suyuti mengartikan kata naskh sebagai penghapusan atau pembatalan hukum sementara Țaha penundaan hukum. 
Penerapan Teori Naskh terhadap Ayat-Ayat Jihād ..... Mokhamad Ali Ridlo \& Abdul Ghofur

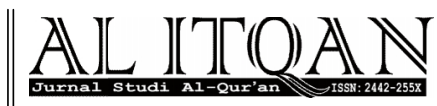

Dilihat melalui konsep kedua tokoh tersebut nampaknya tujuan awal al-Qur'an agar șălihu likulli al-zamān wa al-makān telah pudar. Baik al-Suyuti maupun Țaha sepakat bahwa dalam al-Qur'an terdapat ayat yang tidak dapat berfungsi ketika ayat lain yang menyatakan lain berfungsi. Untuk itu dibutuhkan sebuah format baru, dengan mengambil kelebihan dan mengeliminir kekurangan dari kedua tokoh tersebut. Sebagai contoh, merubah pemaknaan naskh menjadi revisi ${ }^{40}$,

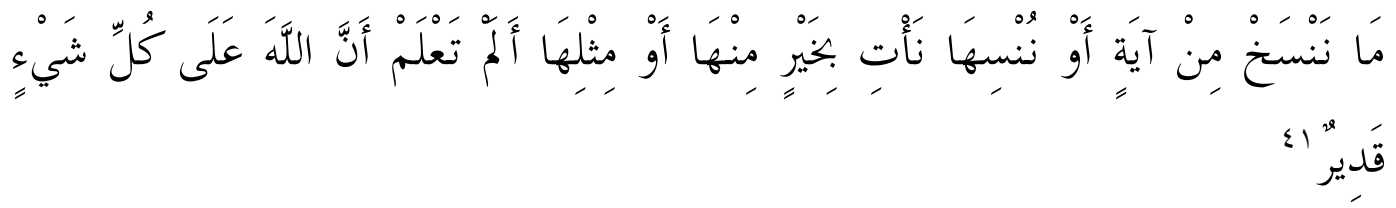

Ayat mana saja yang Kami revisi, atau Kami jadikan (manusia) lupa kepadanya, Kami datangkan yang lebih baik atau yang sebanding dengannya. Tidakkah kamu mengetahui bahwa sesungguhnya Allah Maha Kuasa atas segala sesuatu?

Firman Allah di atas mengisyaratkan naskh terjadi bukan karena ketidak tahuan Allah. Melainkan lebih mengarah kebijakan Allah dalam meringankan dan mendasari ketentuan hukum manusia dengan ketentuan yang sebanding atau lebih baik, sesuai dengan beban dan keterbatasan manusia.

Memaknai naskh sebagai revisi nampaknya mampu menjadi jalan tengah bagi perbedaan konsep naskh al-Suyuti dan TTaha. Memfungsikan seluruh ayat al-Qur'an tanpa harus ada yang terhapus atau ditunda. Sementara ketentuan ayat naskh tetap berdasarkan riwayat șahih dari Nabi Muhammad Șalla Allah 'Alayhi wa Sallam atau sahabat. Dengan demikian, hukum akan lebih bersifat fleksibel, kontekstual sesuai dengan situasi dan kondisi masyarakat. Untuk sekedar contoh, hadis Nabi Șalla Allah 'Alayhi wa Sallam tentang larangan ziarah qubur. Bentuk larangan dan anjuran ziarah dapat berfungsi dalam satu waktu, tergantung dari sudut pandang khitab-nya. Nabi melarang ziarah karena khawatir terjadi kemusyrikan di tengah-tengah para sahabat, dan ketika kekhawatiran tersebut hilang maka larangan itu direvisi menjadi anjuran. Apabila dewasa ini kekahwatiran itu kembali muncul bagi satu komunitas tertentu maka hukum yang difungsikan adalah nas pertama (larangan), sementara komunitas lain yang terhindar akan kemusyrikan diberlakukan nas kedua (anjuran).

\footnotetext{
${ }^{40}$ Dalam Kamus Besar Bahasa Indonesia (KBBI) disebutkan revisi merupakan bentuk peninjauan (pemeriksaan) kembali untuk perbaikan, Lihat Suharso dan Ana Retnoningsih, Kamus Besar Bahasa Indonesia edisi Lux, (Semarang: Widya Karya, 2012), 427.
}

${ }^{41}$ Al-Qur'an, 2 : 106. 


\section{Gambaran Umum Tentang Ayat Jihad}

Dalam al-Qur'an kata jihād diungkap sebanyak 41 kali. Meskipun demikian, bukan berarti semuanya berjuang di jalan Allah, karena terdapat ayat dengan redaksi jihâd, namun untuk pengertian berjuang dan berusaha seoptimal mungkin untuk mencapai sebuah tujuan yang belum tentu benar. Sebagai contoh firman Allah Subhānahu wa Ta'āla,

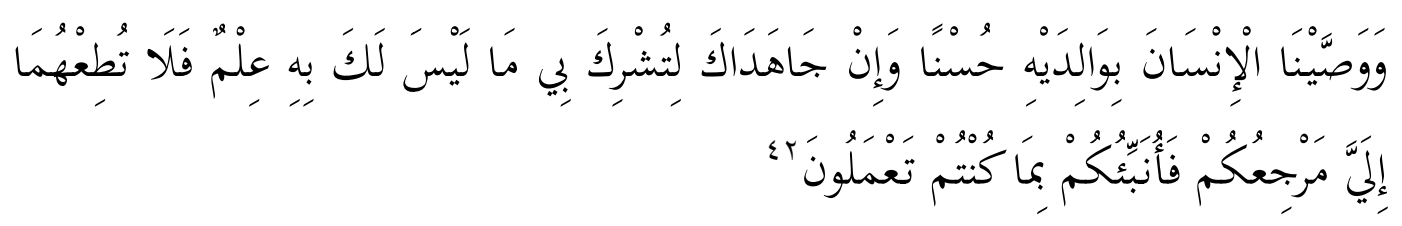

Kami telah wasiatkan kepada manusia untuk berlaku baik kepada kedua orang tuanya, apabila mereka berdua memaksamu untuk menyekutukan Aku dengan sesuatu yan tidak kamu ketahui, jangan kau turuti mereka, kepada Akulah kalian semua kembali dan akan Aku beritahuakan segala yang kamu lakukan

Kata jihād yang berarti berjuang di jalan Allah Subhānahu wa Ta'āla, ditemukan pada tiga puluh tiga (33) ayat, tiga belas (13) kali dalam bentuk fi'il madly (bentuk kata kerja lampau atau past), lima (5) kali fi'il mudlari' (bentuk kata kerja present), tujuh (7) kali fi'il amar (kata kerja perintah), empat (4) kali bentuk masdar (invinitive) dan empat (4) kali dalam bentuk isim fä'il (pelaku).

Apabila ditinjau dari sudut tempat turun ayat (asbāb al-nuz $\bar{u} l$ ), ayat-ayat di atas sebagian turun saat Nabi Șalla Allah 'Alayhi wa Sallam berada di Makkah, dan sebagian lain di Madinah. Meksipun demikian, tidak ada kata sepakat di kalangan ulama dalam menetukan ayat-ayat jihād periode Makkah dan Madinah.

Ayat-ayat periode Makkah pada umumnya menyeru bersabar terhadap tindakan represif musuh. Di samping terus berdakwah di tengah-tengah umat manusia, bersabar merupakan jalan alternatif. Sementara ayat jihād periode Madinah cenderung menyeru menghadapi musuh secara konfrontatif dan memperbolehkan umat Islam untuk membalas. Hal ini sesuai dengan kondisi umat Islam saat itu, siap membalas perlawanan musuh. ${ }^{43}$ Berbagai pengulangan perintah jihād periode Madinah menunjukan bahwa aktifitas jihād dalam Islam saat itu mengalami peningkatan.

\footnotetext{
${ }^{42}$ Al-Qur'an, $29: 8$.

${ }^{43}$ Jalāl al-Dīn al-Suyūti, al-Dur Manthūr F̄̄ Tafsīr bi al-Ma'thūr, (Bairut: Dār al-Fikr, 2003 ), 1: 491
} 
Penerapan Teori Naskh terhadap Ayat-Ayat Jihād .....

Mokhamad Ali Ridlo \& Abdul Ghofur

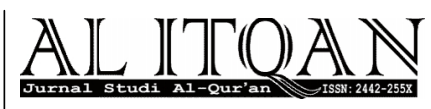

\section{E. Respon al-Suyūti dan Țaha}

Dalam menafsirkan al-Qur'an, mayoritas metode yang digunakan al-Suyuti adalah tahlili yakni sebuah metode menafsirkan al-Qur'an dengan memaparkan segala aspek dalam al-Qur'an sekaligus menerangkan makna dari berbagai seginya. ${ }^{44}$ Ketika menafsirkan suatu ayat al-Suyuti jarang sekali memuat pandangannya. Untuk sekedar contoh firman Allah Subhānahu wa Ta'āla,

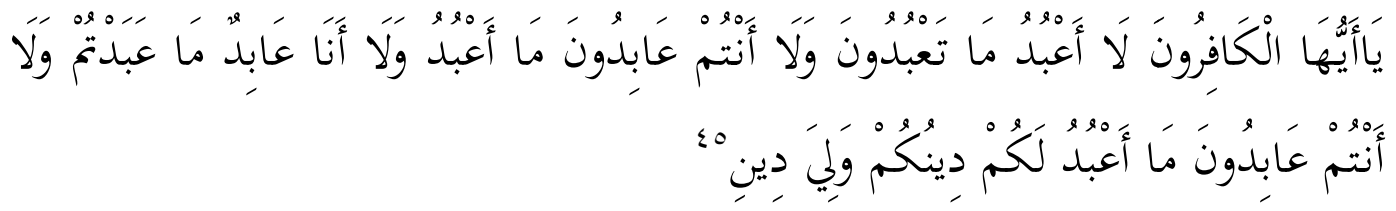

Katakanlah, wahai orang-orang kafir, aku tidak akan menyembah apa yang kamu sembah dan kamupun tidak akan menyembah sesembahan yang aku sembah. Dan aku sama sekali tidak akan menyembah apa yang kamu sembah. Dan kamu tidak akan menyembah yang aku sembah. Bagimu agamamu dan bagiku agamaku.

Ayat ini diturunkan ketika kelompok orang-orang musyrik memberikan negoisasi kepada Nabi Șalla Allah 'Alayhi wa Sallam agar Nabi berkenan menyembah Tuhan mereka dengan jangka waktu satu tahun, begitu pula mereka akan menyembah Allah Subhānahu wa Ta'àla. ${ }^{46}$

Jalāl al-Dīn al-Suyūti selaku penerima konsep naskh, menyakini bahwa ayat dengan subtansi seperti di atas telah dihapus dengan ayat yang memerintahkan jihād. Meskipun hakikat jihād dalam Islam tidak bertujuan merampas harta. Jihād hanya sebuah alternatif terakhir dalam dakwah, untuk mempertahankan diri dari serangan musuh dan menangkis tindakan yang melampaui batas. ${ }^{47}$ Allah Subhānahu wa Ta'āla berfirman,

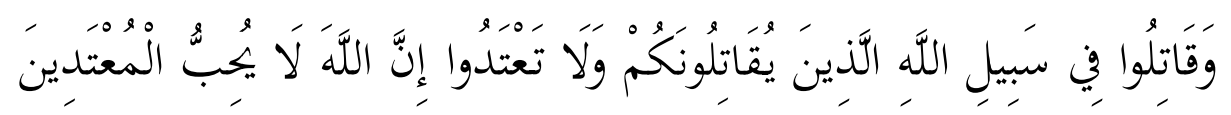

Dan perangilah di jalan Allah orang-orang yang memerangi kamu, (tetapi) janganlah kamu melampaui batas, karena sesungguhnya Allah tidak menyukai orang-orang yang melampaui batas.

Asbāb al-Nuzūl ayat, tekait dengan perjanjian Hudaibiyah. Nabi Șalla Allah 'Alayhi wa Sallam beserta sahabatnya berkonsiliasi dengan orang-orang musyrik untuk kembali ke

\footnotetext{
${ }^{44}$ Nashruddin Ba'idan, Metodologi Penafsiran Al-Qur'an, (Yogyakarta: Glaguh UHIV, 1998), 31

${ }^{45}$ Al-Qur'an, 109 : 1-6

${ }^{46}$ Jalāl al-Dīn al-Mahali, Tafsir al-Qur'an al- 'Ażim, (Surabaya: al-Haramain), 2 : 272.

${ }^{47}$ Muhammad Faiz al-Math, Keistimewaan Islam, (Jakarta: Gema Insani Press, 1995), 127.
} 
Masjidil Haram pada musim haji tahun depan. Namun ketika Nabi dan Umat Islam hendak kembali ke Masjidil Haram, mereka merasa khawatir tidak diperkenankan untuk memasukinya. Kemudian Allah Subhānahu wa Ta'āla menurunkan ayat tersebut. ${ }^{48}$

Dengan menukil beberapa riwayat, al-Suyūti mengatakan bahwa ayat tersebut menjelaskan perintah jihād melawan orang-orang kafir melalui perang, dengan tujuan mempertahankan dan melindungi jiwa dari serangan musuh. Perang dilaksankan dalam rangka defensif bukan ofensif serta tidak diperkenankan berlebihan, dalam arti melarang membunuh perempuan, anak-anak, dan orang tua. ${ }^{49}$ Namun demikian pesan ayat ini tidak absolut, telah dihapus firman Allah Subhānahu wa Ta'āla,

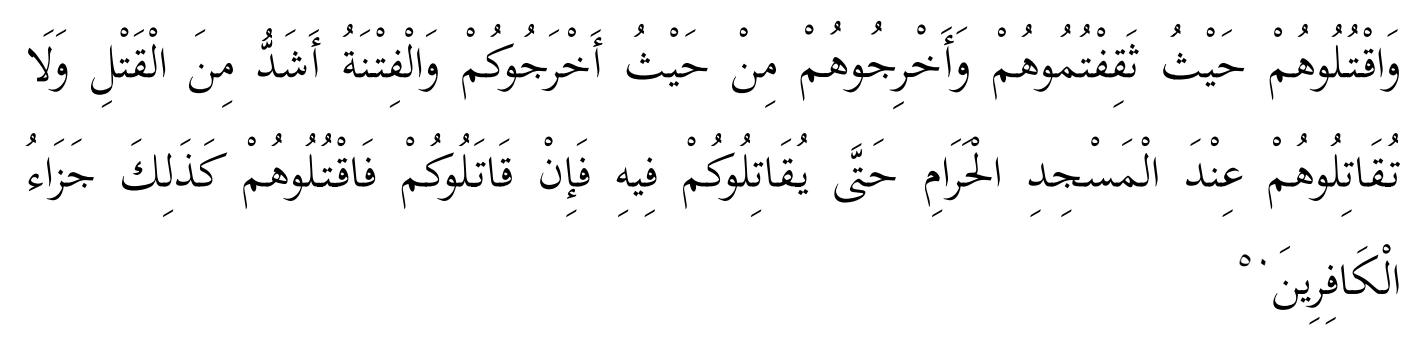

Perangilah mereka dimana saja kamu berjumpa, usirlah mereka sebagiamana mereka mengusir kamu, fitnah (teror) lebih kejam dari pada peperangan. Jangan lawan mereka di masjidil Haram kecuali mereka menyerangmu di sana. Apabila mereka memerangimu lawanlah merekalawanlah mereka, itulah balasan bagi orang-orang kafir. ${ }^{51}$

Selama tidak berada di Masjidil Haram pembatasan objek tidak berlaku. Dimanapun umat Islam bertemu dengan orang kafir perintah berperang harus dilaksanakan, dengan catatan selama mereka tidak menyerang lebih dahulu. Mengartikan al-fitnah sebagai syirik menjadikan al-Suyuti beranggapan bahwa konsekuensi mensekutukan Allah lebih berat daripada perang. ${ }^{52}$ Kemudian ayat ini pun dihapus dengan ayat setelahnya ${ }^{53}$

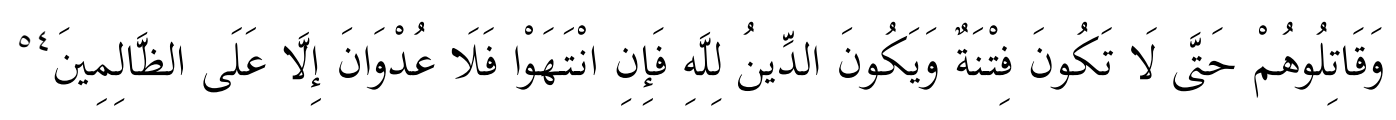

\footnotetext{
${ }^{48}$ Jalāl al-Dīn al-Suyūti, Tafsir al-Qur'an al-Aẓim , 28.

${ }^{49}$ Jalāl al-Dīn al-Suyūti, al-Dur Manthūr, $1: 493$.

${ }^{50}$ Al-Qur'an, 2 : 191

51 Al-Kalibi dari Abī Șālih dari Ilbnu 'Abbas Radliyallahu 'Anhu mengatakan, ayat ini turun saat Suluh Hudaibiyah. Lihat Abī al-Hasan 'Ali bin Ahmad al-Wāhidi, 36.

52 Jalāl al-Dīn al-Suyūti, al-Dur Manthūr, 2 : 494.

${ }^{53}$ Jalāl al-Dīn al-Suyūti, Ibid, $2: 495$.

${ }^{54}$ Al-Qur'an, 2 : 193.
} 
Penerapan Teori Naskh terhadap Ayat-Ayat Jihād ..... Mokhamad Ali Ridlo \& Abdul Ghofur

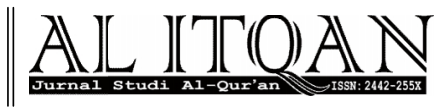

Perangilah mereka sampai tidak ada lagi fitnah dan agama hanya untuk Allah semata. Jika mereka berhenti maka tidak lagi ada permusuhan, kecuali terhadap mereka yang melakukan kedlaliman.

Tidak hanya itu, dalam riwayat yang dikeluarkan Ibnu Abī Shaibah dari Abdu bin Humaid dari Qatadah, al-Suyuti mengatakan pesan hukum surat al-Baqarah ayat 191 juga dihapus oleh surat al-Taubah ayat 5 dan $36 .{ }^{55}$ Nampaknya al-Suyuti memberikan keluasan akan konsep naskh, suatu ayat pada satu sisi menjadi nasīkh dan pada sisi lain menjadi mansūkh.

Sementara Muhammad Mahmūd Țaha, mengajak membangun prinsip penafsiran baru. Memperbolehkan penerapan ayat-ayat al-Qur'an dan Hadis menjadi solusi bagi kebutaan dan keterbatasan hukum fikih. ${ }^{56}$ Diperlukan suatu pengujian secara terbuka terhadap isi al-Qur'an dan Hadis, membentuk dua tahap risalah turunnya wahyu yakni periode Makkah dan Madani.

Pesan-pesan periode Makkah merupakan pesan Islam yang abadi dan fundamental, menekankan martabat inheren pada seluruh umat manusia tanpa membedakan jenis kelamin, kenyakinan agama, ataupun ras. Namun risalah ini kemudian ditolak dengan keras (jihād) saat Nabi Salla Allah 'Alayhi wa Sallam hijrah ke Madinah. ${ }^{57}$

Pada periode Madani pesan al-Qur'an berganti menjadi lebih spesifik, terdapat perbedaan antara laki-laki dan perempuan dalam status hukum dan haknya. Kemudian menjadi dasar dalam hukum fikih, bahkan sampai saat ini masih digunakan sebagai sumber hukum Islam.

Pesan al-Qur'an yang diturunkan di Makkah dan Madinah berbeda bukan karena waktu dan tempat diwahyukan, melainkan karena perbedaan kelompok sasaran. Pergantian audien dilatarbelakangi karena terjadi penolakan terhadap pesan al-Qur'an yang turun lebih dahulu di Makkah melalui kekerasan. ${ }^{58}$ Meskipun demikian, tidak berarti aspek pesan Makkah terhapus, namun hanya ditunda dan tetap menjadi sumber hukum Islam serta ditangguhkan pelaksanaannya dalam kondisi yang tepat di masa akan datang. ${ }^{59}$

Dalam risalah pertama, Țaha menyampaikan tentang Islam. Perbedaan antara muslim dan mukmin hanya pada tingkatannya saja, tidak berbeda secara esensi. Prinsip dasar Islam

\footnotetext{
55 Jalāl al-Dīn al-Suyūti, al-Dur Manthūr, 2 : 495.

${ }^{56}$ Abdullah Ahmed an-Na'im, Dekontruksi Syari'ah, 70.

57 Ibid, Lihat juga Muhammad Mahmūd Țaha, al-Risalah al-Thaniyah, 21.

58 Ibid, 21

${ }^{59}$ Abdullah Ahmed an-Na'im, Dekontruksi Syari'ah, 103-104.
} 


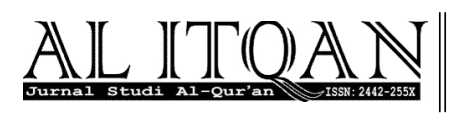

Penerapan Teori Naskh terhadap Ayat-Ayat Jihād .....

Mokhamad Ali Ridlo \& Abdul Ghofur

manusia memiliki kebebasan yang bertanggung jawab tanpa melanggar hak orang lain. Dalam al-Qur'an Allah Subhānahu wa Ta'āla berfirman:

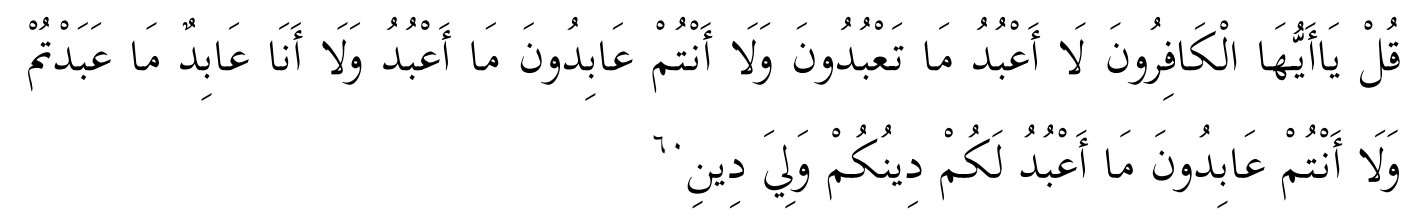

Katakanlah, wahai orang-orang kafir, aku tidak akan menyembah apa yang kamu sembah dan kamupun tidak akan menyembah sesembahan yang aku sembah. Dan aku sama sekali tidak akan menyembah apa yang kamu sembah. Dan kamu tidak akan menyembah yang aku sembah. Bagimu agamamu dan bagiku agamaku.

Pada awal penyebaran Islam tidak dilakukan dengan paksaan, namun dilaksankan secara persuasif sehingga masyarakat Makkah masuk Islam dengan sukarela. ${ }^{61}$ Selanjutnya, pasca Nabi Șalla Allah 'Alayhi wa Sallam hijrah ke Madinah pesan itu berbalik, Allah memerintahkan Nabi dan para sahabatnya berperang melawan umat non-muslim dalam kondisi apapun sebagimana di pahami dari firman Allah Subhānahu wa Ta'āla,

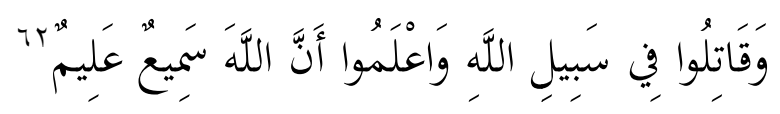

Berperanglah di jalan Allah, ketahuilah bahwa Allah Maha mendengar lagi Maha mengetahui.

Implikasi dari perintah tersebut menimbulkan perbedaan lain tentang pesan Makkah dan Madinah. Sebagai contoh dalam masalah perbudakan. Ketika terjadi peperangan umat Islam dan non-Islam maka tawanan perang akan menjadi budak bagi pemenang. Islam muncul di tengah masyarakat yang memiliki tradisi perbudakan. Perbudakan menjadi salah satu bagian yang menyatu dalam sendi kehidupan masyarakat waktu itu. Selanjutnya Islam membatasinya, dengan memberikan kebebasan bagi tawanan perang untuk membebaskan diri melalui harta atau kemampuan untuk diajarkan pada umat Islam. Țaha menyatakan bahwa persoalan perbudakan merupakan salah satu hal yang dihapus melalui kedatangan Islam. ${ }^{63}$

Dalam risalah kedua, Țaha membicarakan tentang konsep-konsep ideal yang diimplementasikan dalam masyarkat muslim menuju masyarakat Islam sejahtera. Menurut Ṭaha negara dapat terbentuk dan berkembang apabila ditopang oleh masyarakat yang baik,

\footnotetext{
${ }^{60}$ Al-Qur'an, 109 : 1-6.

${ }^{61}$ Muhammad Mahmūd Țaha, Risalah al-Tsaniyat, 132-137.

${ }^{62}$ Al-Qur'an, 2 : 244

${ }^{63}$ Muhammad Mahmūd Ṭaha, Risalah al-Tsaniyat, 137-138.
} 
Penerapan Teori Naskh terhadap Ayat-Ayat Jihād .....

Mokhamad Ali Ridlo \& Abdul Ghofur

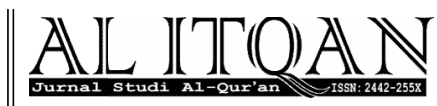

yakni mengedepankan beberapa persamaan hak atau keadilan. Misalnya keadilan ekonomi: sosialisme, keadilan politik: demokrasi, dan keadilan sosial: penghapusan kelas dan diskriminasi. ${ }^{64}$ Selain itu, dibutuhkan juga sistem pendidikan ilmiah yang mengarahkan individu untuk mengembangkan diri secara bebas tanpa dilandasi ketakuatan terhadap apapun. $^{65}$

\section{F. Implikasi Konsep Naskh Terhadap Ayat Jihäd}

Jihād bukanlah sesuatu yang baru bagi umat Islam. Pada masa Nabi Șalla Allah 'Alayhi wa Sallam fenomena jihād sudah menjadi bagian ajaran Islam yang sangat penting. Seruan jihäd bukan sekedar perintah Nabi, namun perintah haq yang termaktub dalam alQur'an. Hanya saja fenomena jihād pada masa itu tidak sama dengan konsep jihād yang diimplementasikan saat ini.

Terma jihād yang diusung al-Qur'an telah mengalami beberapa pergeseran dalam masyarakat Muslim. Entah karena pemahaman yang parsial terhadap ayat al-Qur'an atau terpengaruh akan konsep naskh, yang jelas sebagian kelompok radikal dalam Islam mengatas namakan ayat-ayat jihād untuk melegitimasi apa yang mereka lakukan.

Manyoritas ulama menyakini legislasi disyariatkan jihād terbagi dalam empat fase. Pertama, sebelum hijrah yakni ketika perang dilarang. Kedua fase setelah hijrah, ketika perang defensif melawan orang musyrik. Ketiga, fase perang ofensif melawan orang-orang musyrik diijinkan. Tiga ayat yang menjadi dasar kebolehan perang defensif pada fase sebelumnya dianggap di-naskh surat al-Baqarah ayat 193. Keempat, fase ketika perang menjadi kewajiban mutlak, dalam arti perang menjadi kewajiban yang tidak bisa ditawar, sebagaimana dijelaskan dalam surat al-Baqarah ayat 216 dan al-Taubah ayat $36 .{ }^{66}$ Kronologi tersebut menjadi awal kontroversi berkepanjangan dari penerapan teori naskh terhadap ayatayat jihād. Dalam hal ini Ibnu Hajar al-Haitami dalam Tuhfat al-Muhtaj menganggap perang tanpa batas $(i t l a \bar{q})$ adalah akibat di-naskh ayat-ayat damai dan ayat perang defensif. ${ }^{67}$

Meskipun demikian, masih belum ada kata sepakat di kalangan ulama mengenai ayat yang menjadi rujukan untuk fase diwajibkan perang secara mutlak. Di kalangan fikih Hanafi,

\footnotetext{
64 Ibid., 153.

65 Ibid, 150

${ }^{66}$ Al-Syafi'I, Ahkām al-Qur'an, (Bairut: Dār al-Kutub al-'Ilmiyah, tth), 13-15.

${ }^{67}$ Ibnu Hajar al-Haitami, Tuhfat al-Muhtāj, dalam 'Abd al-Hamid al-Sharwani, Hawashi Tuhfat al-Muhtāj bi Sharh al-Minhāj, (Mesir: Maṭba’at Mușțafā Muhammad, tth), 212.
}

AL-ITQĀN, Volume 2, No. 1, Februari 2016103 
al-Sarakhsī mengemukakan kronologi yang subtansinya sama, namun merujuk surat alTaubah ayat 5. Akan tetapi al-Sarkhsi tidak menyebut terdapat naskh, sebab surat al-Anfāl ayat 61 yang mendasari perang defensif pada fase sebelumnya turun lebih akhir dibandingkan al-Baqarah ayat 193, kecuali apabila dianggap di-naskh al-Taubah ayat $5 .{ }^{68}$ Tidak hanya itu, surat al-Taubah juga dianggap telah me-naskh kasus diperbolehkan menebus tawanan perang. ${ }^{69}$

Ibn 'Ābidīn dalam Radd al-Mukhtār menjelaskan fase akhir legislasi sebagai fase diperintahkan perang tanpa batas dengan merujuk al-Baqarah ayat $190 .^{70}$ Sedangkan alTaubah ayat 5 menurutnya hanya berisi perintah perang ofensif dengan pembatasan waktu pada fase sebelumnya. Fakhr al-Dīn 'Uthmān bin'Alī al-Zaya'i dalam Tabyīn al-Haqāiq menjelaskan empat fase kronologi legislasi perang yang berbeda yakni fase ketika perang dilarang dijelaskan surat 15 ayat 85, fase kebolehan perang defensif dalam surat 22 ayat 39, fase perang ofensif bersyarat dijelaskan al-Taubah ayat 5 dan fase perang mutlak dalam alBaqarah ayat $193 .^{71}$

Terlepas dari polemik di atas, yang jelas legislasi jihād tidak diwajibkan secara langsung namun melalui beberapa fase. Fase akhir kronologi legislasi jihād adalah perintah perang, menjadi kewajiban abadi dan berlaku hingga hari kiamat. Dengan kronologis legislasi jihād, al-Suyuti menyatakan ayat damai telah di-naskh ayat jihād. Sedangkan Taha justru sebaliknya, ayat jihād di-naskh oleh ayat damai.

Melalui teori naskh al-Suyuti, kewajiban jihād tidak hanya menjadi ketentuan final, melainkan tidak bisa naskh lagi. Akibatnya jihād dipandang sebelah mata, kelompok garis keras menjadikannya sebagai rujukan dalam prinsip hidup. Dimanapun ditemukan kemunkaran, maka peran jihâd diterapkan. Berbeda dengan al-Suyuti, teori Ṭaha yang berkarakter progresif yakni berorientasi ke depan dengan ketentuan tertentu dan bergerak sirkular masih mempertimbangkan hukum yang pernah ditunda. Implikasinya umat Islam bersifat pasif, ketika mengetahui Islam tidak lagi yu'la wa la yu'la 'alaih umat Islam lebih memilih berdiam diri dan menyaksikan Islam direndahkan, sebagaimana tragedi di Palestina dan Myanmar.

\footnotetext{
${ }^{68}$ Al-Sarakhsi, al-Mabsūt, (Bairut: Dār al-Fikr, 2000), 3-4.

69 Ibid, 41.

${ }^{70}$ Ayat ini menjadi rujukan al-Syafi'i dalam menjelaskan kronologi disyariatkan jihad.

${ }^{71}$ Fakhr al-Dīn 'Uthmān bin'Al̄̄ al-Zaya'i, Tabyīn al-Haqāiq Sharh Kanz al-Daqāiq, (Kairo: Dār al-Kutub alIslām), 241.
} 
Penerapan Teori Naskh terhadap Ayat-Ayat Jihād ..... Mokhamad Ali Ridlo \& Abdul Ghofur

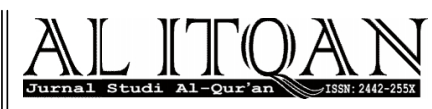

Baik menggunakan teori al-Suyuti maupun Țaha, nampaknya masih belum menjawab problem kontemporer. Pada satu sisi harus mempertahankan perdamaian dengan menjunjung tinggi nilai-nilai persamaan dan toleransi namun pada sisi lain harus mampu mempertahankan norma-norma Islam. Naskh dengan makna revisi menjadikan dua sisi itu dapat digunakan secara bersamaan. Baik ayat damai maupun ayat jihād dapat diaplikasikan dalam satu waktu, namun dalam konteks berbeda. Untuk sekedar gambaran, ayat yang diklaim sebagai rujukan diperbolehkan perang,

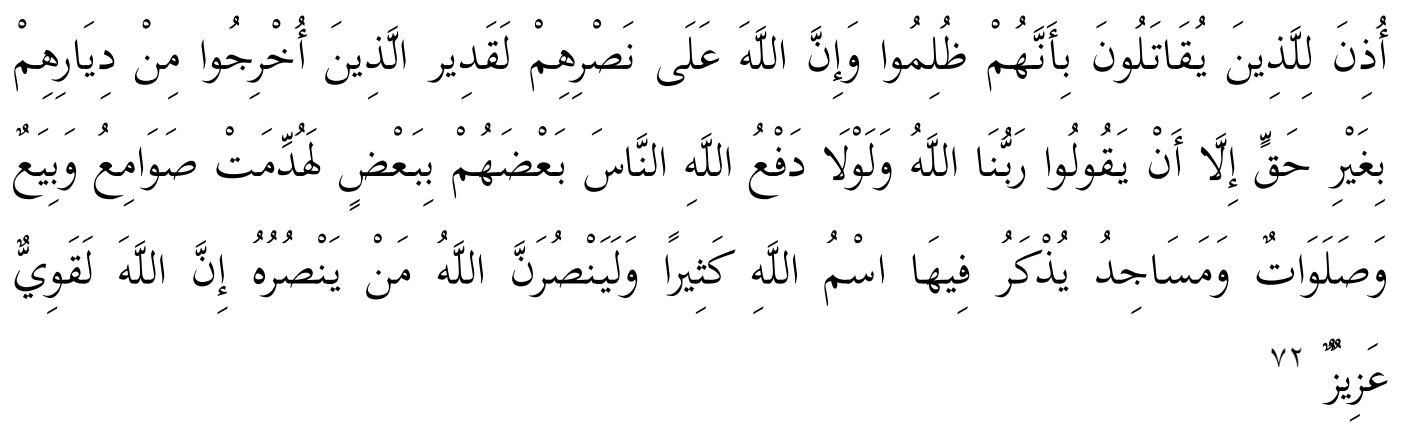

Diizinkan bagi orang-orang yang diperangi dan dianiyaya untuk membalas dengan perang. Allah sungguh Maha Kuasa untuk memberikan mereka pertolongan. ${ }^{73}$

Ayat di atas mengilustrasikan bahwa konsep al-qital mempunyai kesamaan pandangan dengan terma jihâd, dalam arti membunuh, melaknat dan berperang. Di samping itu, ayat tersebut juga diklaim menjadi ayat yang pertama kali turun berkenaan dengan perang. Melalui ayat ini sebagian mufasir menganggap surat ini termasuk Madani. Mengenai asbāb al-nuzūl Ibnu Abbas menjelaskan, ketika Nabi Șalla Allah 'Alayhi wa Sallam diusir dari Makkah Abu Bakar mengatakan, "mereka mengusir Nabi. kami adalah milik Allah dan akan kembali kepada-Nya, sungguh mereka akan binasa. Kemudian Allah menurunkan ayat tersebut. ${ }^{74}$

Secara tidak langsung, ayat tersebut memberikan isyarat alasan yang mendasari mengapa pada periode Madinah diperbolehkan perang. Saat di Makkah pengikut Nabi masih sedikit sehingga belum mampu melawan. Melalui ayat الَّنِينَ أُخْرُو ا مِنْ دِيَار هِهْ , di anggap mampu menjadi bukti kuat pada saat ini Nabi telah mampu serta menunjukan bahwa ayat ini turun di Madinah atau setelah Nabi hijrah. Selain itu, istisna munqoti' dalam firman Allah, إنَّا أنْ يَقُولوُ mengisyaratkan alasan utama mereka memusuhi Nabi dan sahabat serta mengusir dari

\footnotetext{
${ }^{72}$ Al-Qur'an, $22: 39$.

${ }^{73}$ Ayat ini meruapakan ayat pertama dalam al-Qur'an yang menyinggung tentang peperangan.

74 'Imad al-Din Abī al-Fida' Isma'il Ibnu Kathir, Tafsīr al-Qur'an al-Aẓ̄m, (Bairut: Dār al-Kutub al-'Ilmiyah), 5: 433.
} 
kampung halamannya, yakni karena Nabi membawa hal baru, mengesakan Allah Subhānahu wa Ta'āla.

Pada tahap selanjutnya, perang tidak sekedar diperintahkan namun juga diwajibkan. Allah Subhānahu wa Ta'āla berfirman,

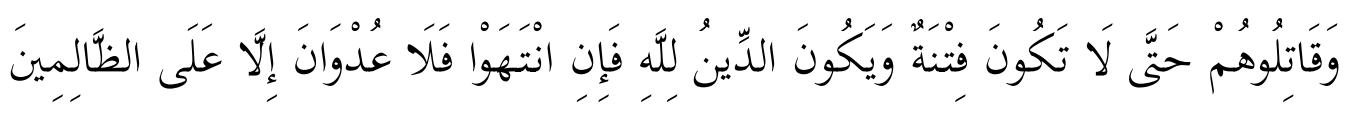

Dan perangilah mereka itu hingga tidak ada lagi fitnah dan (sehingga) ad-dīn (agama itu hanya) untuk Allah. Jika mereka berhenti (dari memusuhi kalian), maka tidak ada (lagi) permusuhan (antara kalian dan mereka), kecuali terhadap orang-orang yang zalim

Ayat sebelumnya terkesan menjelaskan akhir diperintahkan perang, "kemudian ketika mereka berhenti --dari memerangi kalian-- maka ampunan Allah bagi mereka". Namun kemudian ayat ini seperti menunjukan perintah perang datang kembali. Apabila hal ini dibenarkan, apa bukan berarti menunjukan bahwa Allah inkonsisten dalam menentukan hukum, atau ayat ini sekedar bentuk antisipasi ketika orang-orang kafir tidak berhenti atau berhenti namun kambuh lagi, atau hanya sebagai penguat ayat sebelumnya.

Sehubungan dengan takwīl ayat di atas al-Suyuti mengartikan kata "fitnah" dengan syirik menyekutukan Allah Subhānahu wa Ta'āla. Ketika masih terdapat kemusyrikan maka jihād tidak terhenti. Menurut penulis pemaknaan ini lebih sesuai, dengan meninjau ayat setelahnya, “dan agama hanya milik Allah". Hal ini menjadi alasan jihād tetap ditegakan dan dianggap kewajiban permanen. Selama orang-orang kafir tetap tidak beriman, kewajiban jihād melalui perang untuk menghapus kufr di hati mereka tetap berlaku.

Meskipun demikian perlu diperhatikan kembali ayat sebelumnya, kewajiban jihād pada ayat ini merupakan lanjutan dari ayat sebelumnya. Perintah jihād diawali oleh keadaan dimana musuh telah menyerang, orang-orang kafir mengangkat senjata dan menyatakan perang. Selanjutnya ketika mereka berhenti menyerang maka perintah perang ditiadakan sebab Allah telah memberikan ampunan kepada mereka. Dengan demikian, ayat ini hanya sebagai bentuk antisipasi ketika orang-orang kafir tidak berhenti maka sebagai alternatif memerangi mereka sampai mereka mau masuk Islam. Nampaknya bentuk ta'wil seperti ini lebih sesuai dengan kondisi saat ini, dimana tidak sedikit musuh-musuh Islam menyatakan perang dengan Islam. Sebagai contoh Serangan desa Thuye Tha Mein Myanmar. Tepatnya pada tanggal 23 Juni ketegangan agama meningkat di Myanmar, pihak garis keras 
Penerapan Teori Naskh terhadap Ayat-Ayat Jihād ..... Mokhamad Ali Ridlo \& Abdul Ghofur

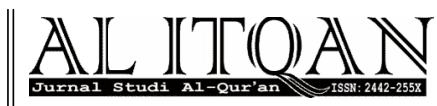

nasionalis Buddha melakukan tindakan kekerasan terhadap warga Muslim. ${ }^{75}$ Jauh sebelum itu, tercatat lebih 178 jiwa Palestina tewas dan 16.200 lainnya terluka akibat serangan pasukan keamanan Zionis Israel di sepanjang tahun $2015 .^{76}$

Kewajiban jihād untuk saat ini hanya berlaku dengan kondisi sebagaimana di atas. Perintah jiha $\bar{d}$ hanya sebagai bentuk revisi dari anjuran untuk saling menghargai dan toleransi. Dalam arti, pada saat di Makkah umat Islam belum mampu melawan orang kafir karena masih lemah dan masih dalam kategori minoritas, sehingga wajar apabila Allah Subhānahu wa Ta'āla memerintahkan mereka untuk bersabar dan saling menghargai. Namun ketika umat Islam telah menjadi banyak dan kuat, perintah itu direvisi dengan melawan mereka yang memusuhi.

Sementara dalam konteks Indonesia tampaknya kurang relevan untuk menerapkan konsep jihâd. Indonesia merupakan salah satu negara dengan populasi penduduk Muslim terbesar di dunia, menjadi negara yang tidak hanya multi suku, etnik dan agama, namun juga multibudaya. ${ }^{77}$ Untuk konteks Indonesia tampaknya yang lebih dibutuhkan adalah ayat-ayat yang berorentasi saling menghargai dan toleransi yakni ayat yang telah di-naskh (revisi) ayat jihād.

Menciptakan kerukunan dan jihād sebenarnya tidak dapat disatukan, sebab kerukunan menciptakan aman, tenang dan damai. Sementara jihād menciptakan tumpahnya darah, kehancuran dan penderitaan yang berkepanjangan. Di Indonesia, dimana umat Islam dan nonIslam tidak berada dalam posisi yang saling berhadapan maka perlu disandingkan dan didialogkan dengan ayat lain yang menganjurkan toleransi, kasih sayang dan tolong menolong antar sesama.

Sikap umat Islam tidak selamanya harus memusuhi non-muslim. Terdapat waktu dimana umat Islam harus menolong dan bekerjasama. Wujud dari bingkai tersebut dapat tercermin dari sirah Nabi Muhammad Salla Allah 'Alayhi wa Sallam yang menampilkan kerukunan, toleransi antar agama dan umat beragama dengan pemerintah. Beberapa konsep kerukukan yang ditawarkan Nabi Șalla Allah 'Alayhi wa Sallam dan para sahabatnya pada

\footnotetext{
75 Lihat, http://www.bbc.com/indonesia/majalah/2016/06/160627_trensosial_burma_masjid diakses pada 5 Agustus 2016

76 Lihat, http://www.kiblat.net/2016/01/08/ini-jumlah-korban-agresi-israel-di-palestina-selama-2015/ diakses pada 5 Agustus 2016

77 Ali Maksum, Pluralisme dan Multikulturalisme : Paradigma baru PAI di Indonesia, (Yogyakarta : Aditya Media Publising, 2011), 13.
} 
saat itu, menurut penulis mampu membentengi konflik perbedaan keyakinan yang terjadi di Indonesia dewasa ini. Di antara konsep tersebut yaitu:

a. Penghargaan terhadap perbedaan agama, sebagaimana dijelaskan dalam firman Allah Subhānahu wa Ta'āla tentang tidak ada paksaan dalam beragama.

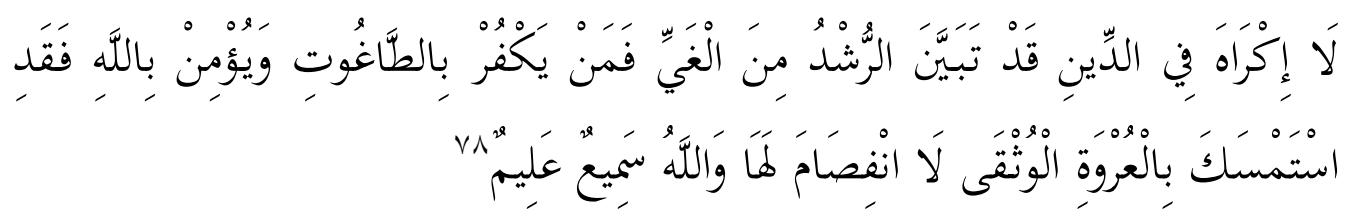

Tidak ada paksaan untuk (memasuki) agama (Islam); sesungguhnya telah jelas jalan yang benar daripada jalan yang sesat. Karena itu barang siapa yang ingkar kepada thaghut dan beriman kepada Allah, maka sesungguhnya ia telah berpegang kepada buhul tali yang amat kuat yang tidak akan putus. Dan Allah Maha Mendengar lagi Maha Mengetahui.

Terkait asbāb al-nuzūl, Al-Suyuti dalam al-Dur al-Manthur menukil sebuah riwayat dari Ibnu Jarīr dari Ibnu Yasar dari Ibnu Abu Addi dari Syu'bah dari Abu Bisyr dari Sa'id Ibnu Jubair dari Ibnu Abbas, dia mengatakan dahulu terdapat seorang wanita yang selalu mengalami kematian anaknya. Kemudian dia bersumpah kepada dirinya sendiri, “Apabila anakku kelak hidup, akan saya jadikan dia seorang Yahudi”. Ketika Bani Nadzir diusir dari Madinah, di tengah mereka terdapat anak-anak Ansar. Lalu mereka berkata, "Kami tidak akan menyeru anak-anak kami masuk Islam. Kemudian Allah menurunkan ayat tersebut. ${ }^{79}$

Awal kedatangan Islam, untuk memperbanyak komunitas Islam tidak perlu terjadi paksaan. Pemaksaan terjadi ketika suatu yang dipaksakan tidak memiliki hakikat dan kebenaran, atau hujah dan bukti yang kuat. Sekilas ayat di atas mengisyaratkan akan kesempurnaan ajaran Islam, sempurna bukti-buktinya, kejelasan ayat-ayat dan kebenaran serta jalan yang lurus. Siapa pun yang telah mengetahui ajarannya tentu tidak akan menolaknya, kecuali yang durhaka. Namun demikian tidak ada paksaan apabila tidak mau masuk Islam. "Sungguh telah jelas jalan kebenaran dari jalan sesat", ayat tersebut menjadi pendukung karena disertai bentuk taukid yakni kata qad. Ketika kebenaran telah tampak, namun mereka tetap enggan mengakui Islam selanjutnya dikembalikan kepada Allah Subhānahu wa Ta'āla.

b. Allah menciptakan manusia berbangsa dan bersuku. Dalam al-Qur'an Allah berfirman,

\footnotetext{
${ }^{78}$ Al-Qur'an, 2: 2

${ }^{79}$ Jalāl al-Dīn al-Suyūti, al-Dur Manthūr, 2: 164.
} 


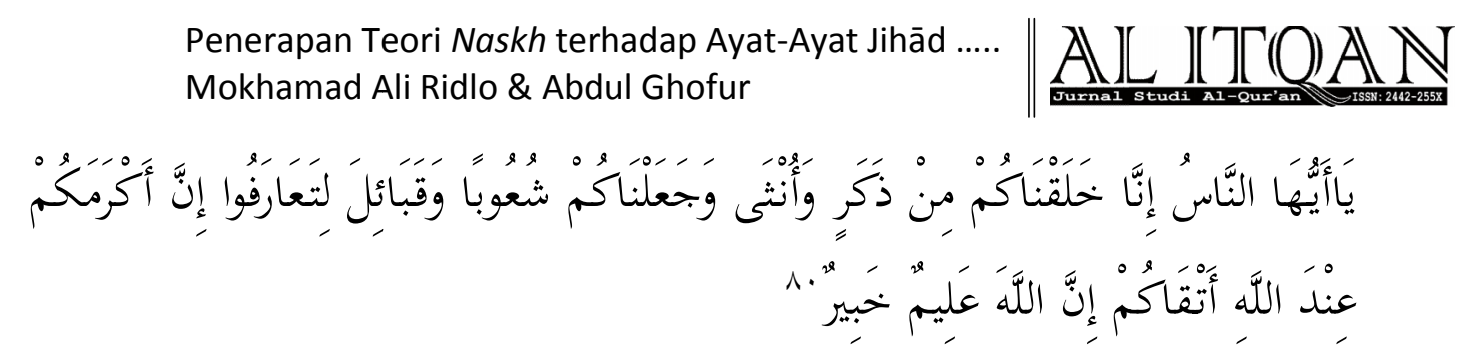

Wahai manusia, Sesungguhnya kami menciptakan kamu dari seorang laki-laki dan seorang perempuan dan menjadikan kamu berbangsa-bangsa dan bersuku-suku supaya kamu saling mengenal. Sesungguhnya orang yang paling mulia diantara kamu disisi Allah ialah orang yang paling taqwa diantara kamu. Sesungguhnya Allah Maha mengetahui lagi Maha Mengenal.

Diriwayatkan Ibnu Abi Hatim bersuber dari Ibnu Abi Mulaikah, pada saat fathu Makkah Bilal naik ke atas Ka'bah untuk mengumandangkan adzan. Beberapa sahabat mengatakan, “Apakah pantas budak hitam ini adzan di atas Ka'bah ?”, kemudian sebagian lain menjawab, "Sekiranya Allah membenci orang ini, pasti Dia akan menggantinya.". 81

Ayat di atas menjelaskan akan adanya persamaan hak manusia yakni persamaan secara universal tanpa membedakan suku, bangsa, agama, ras, kedudukan, dan keturunan. Turun sebagai penegasan dalam Islam tidak ada diskriminasi, yang paling mulia adalah

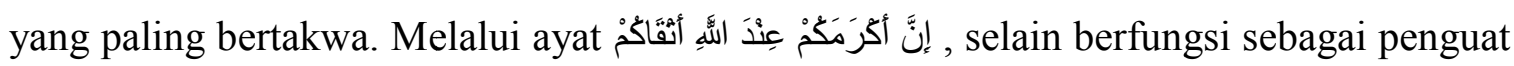
namun juga mengisyaratkan Allah tidak pernah mempermasalahkan perbedaan, ketakwaan dan kekufuran seorang hamba tidak mengurangi eksistensi ke-Tuhan-an.

Dengan demikian, penulis berkesimpulan bahwa penyelesaian kontradiksi antar ayat jihâd dan damai melalui naskh dapat dibenarkan. Akan tetapi dalam konteks kontemporer saat ini bukan berarti pembatalan atau penundaan hukum, sebagaiamana yang digagas al-Suyuti dan Taha. Selain mengembalikan tujuan al-Qur'an agar dapat șālih al-zamān wa makān juga memberlakukan seluruh ayat al-Qur'an lebih dibutuhkan. Melaui pemaknaan revisi, baik ayat-ayat damai maupun jihād dapat dipergunakan dalam satu waktu namun dalam konteks berbeda. Pada satu sisi dibutuhkan ayat-ayat jihād namun pada sisi yang lain perlu adanya bentuk toleransi agar tercipta baldatun tayyibatun wa rabbu al-ghofür. Kemampuan Islam untuk membangun kerukunan umat beragama dalam sisitem kehidupan sosial tidak diragukan, sebab menjadi bagian vital agama Islam. Sulit dibayangkan kemajuan peradaban Islam di era Nabi sampai Abasiyyah tanpa peran dan andil penganut umat beragama lain.

\footnotetext{
${ }^{80}$ Al-Qur'an, 49: 13.

${ }^{81}$ Jalāl al-Dīn al-Suyūti, al-Dur Manthūr, 9: .267.
} 


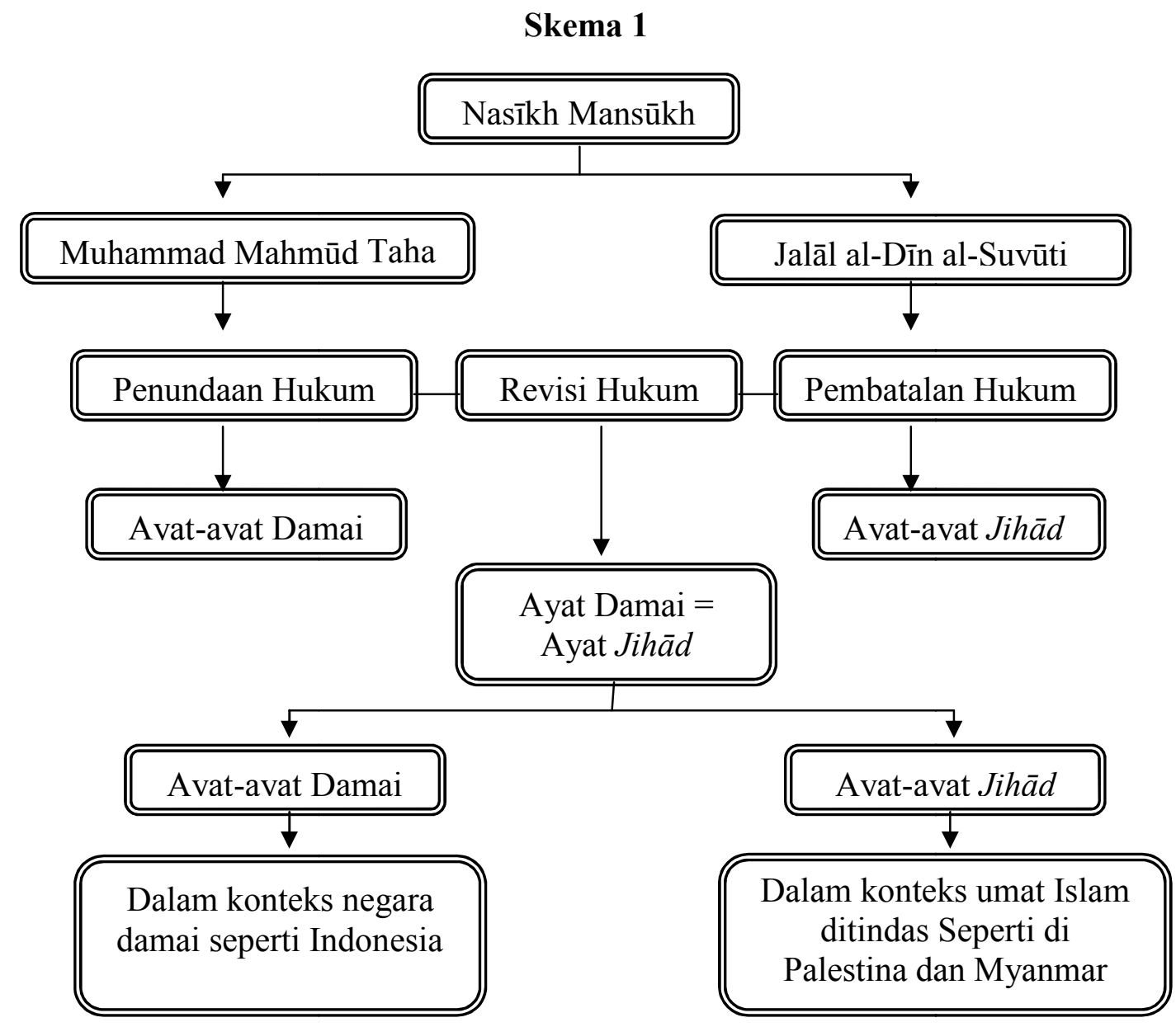

\section{G. Kesimpulan}

Dalam perjalanan sejarah, naskh memiliki catatan perdebatan panjang. Sejarah menunjukan perdebatan terus berlanjut dan tidak memiliki titik muara yang sama. Baik alSuyuti maupun Taha menjadikan al-Baqarah ayat 106 sebagai rujukan untuk melegitimasi keberadaan naksh. Al-Suyuti masih terlihat apresiatif terhadap konsep tradisionalis, yaitu menghilangkan hukum lama dengan hukum baru, ataupun mengganti hukum lama dengan hukum baru. Sementara Taha cenderung mengartikan naskh sebagai penundaan hukum. Dalam arti menghapuskan sementara waktu, dan ketika sampai waktunya hukum itu akan berlaku kembali.

Dalam menentukan ayat nakh al-Suyūti sangat selektif. Terdapat beberapa ketentuan yang harus dipenuhi agar suatu ayat dapat digolongkan nasīkh dan mansūkh. Naskh hanya bisa terjadi melalui riwayat șahih dari Nabi Șalla Allah 'Alayhi wa Sallam atau ucapan sahabat dan tabi'in. Berbeda dengan al-Suyuti, Țaha memberikan kebebasan dalam menentukan ayat naskh. Pemberlakuan ayat tergantung situasi dan kondisi, naskh bersifat 
Penerapan Teori Naskh terhadap Ayat-Ayat Jihād .....

Mokhamad Ali Ridlo \& Abdul Ghofur

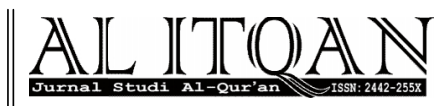

tentatif sesuai dengan kebutuhan. Dalam arti, ayat mana yang dibutuhkan pada masa tertentu maka ayat itulah yang diberlakukan, sedangkan ayat yang tidak diperlukan dihapus.

Pemaknaan naskh sebagai revisi selain mengembalikan fungsi al-Qur'an yang universal yakni șālihu likulli al-zamān wa al-makān, namun juga dianggap mampu menjadi jalan tengah dari kedua konsep naskh di atas. Memfungsikan seluruh ayat al-Qur'an tanpa harus ada yang terhapus atau ditunda. Implikasinya, hukum akan lebih bersifat fleksibel tidak konklusif, kontekstual sesuai dengan situasi dan kondisi masyarakat, namun tetap berdasarkan sumber-sumber yang valid (riwayat șahih).

Melalui naskh, al-Suyuti menyatakan ayat damai telah di-naskh ayat jihād. kewajiban jihād tidak hanya menjadi ketentuan final, melainkan tidak bisa naskh lagi. Pemahaman lain datang dari Țaha, implikasi naskh menjadikan pemahamannya bertolak belakang dengan alSuyuti. Dia menyatakan ayat jihād telah di-naskh ayat damai. Melalui makna revisi, kontradiksi antar dua pemahaman itu dapat digunakan secara bersamaan. Baik ayat damai ataupun ayat jihād dapat diterapkan dalam satu waktu, namun dengan konteks berbeda. Misalnya dalam konteks di mana umat Islam ditindas dan hak-hak beragamanya dibatasi seperti di Palestina dan Myanmar ayat jihād lebih dibutuhkan. Sementara untuk konteks negara damai dimana umat Islam bisa menjalankan kewajiban-kewajiban agamanya seperti di Indonesia ayat toleransi lebih dikedepankan.

\section{DAFTAR PUSTAKA}

Azra, Azyumardi. Konflik Baru Antar Peradaban: Globalisasi, Radikalisme \& Pluralitas. Jakarta: Rajagrafindo Perkasa, 2002.

Ba'idan, Nashruddin. Metodologi Penafsiran Al-Qur'an. Yogyakarta: Glaguh UHIV, 1998.

Baidlowi, Ahmad. Mengenal Thabathaba'i dan Kontroversi Nasīkh Mansūkh. Bandung : Nuansa, 2005.

Dewan Redaksi. Ensiklopedi Islam. Jakarta : Ichtiar Baru, 1994.

Dzahabi (al), Muhammad Husain. al-Tafsīr Wa al-Mufassirūn. ttp : Makatabah Wahbah, tth.

Haitami (al), Ibnu Hajar. Tuhfat al-Muhtāj, dalam 'Abd al-Hamid al-Sharwani, Hawashi Tuhfat al-Muhtāj bi Sharh al-Minhāj. Mesir: Maṭba'at Muștafā Muhammad, th.

Hayy (al), Abi al-Falah Abdu. Syadarat al-Dzahab. ttp : tnp, th.

Hitami, Munzir. Pengantar Studi al-Qur'an; Teori dan Pendekatan. Yogyakarta : LKIS, 2012.

Ibnu Kathir, 'Imad al-Din Abī al-Fida' Isma'il. Tafsīr al-Qur'an al-Az̄ìm. Bairut: Dār alKutub al-'Ilmiyah. 
Jauzy (al), Ibnu. Nawāsikh al-Qur'an. Madinah : Maktabah al-'Arabiyah al-Su'udiyah, 1984.

Mahali (al), Jalāl al-Dīn. Tafsir al-Qur'an al- 'Ażim. Surabaya: al-Haramain.

Maksum, Ali. Pluralisme dan Multikulturalisme : Paradigma baru PAI di Indonesia. Yogyakarta : Aditya Media Publising, 2011.

Math (al), Muhammad Faiz. Keistimewaan Islam. Jakarta: Gema Insani Press, 1995.

Mun'im, Zainul. "Teori Nasīkh Mansūkh al-Qur'an Sebagai Pembaharuan Hukum Islam”. Skripsi di UIN Sunan Kalijaga, Yogyakarta, 2013.

Mustaqim, Abdul. "Epistimologi Tafsir Kontemporer, Studi Komparatif antara Fazlur Rahman dan Muhammad Syahrur". Disertasi : UIN Sunan Kalijaga Jogjakarta, 2007.

Mustaqim, Abdul. Penelitian al-Qur'an dan Tafsir. Yogyakarta : Idea Press, 2014.

P.J Bearman, dkk, The Encyclopedia of Islam. Leiden : Brill, 2000.

Qatțān (al), Manna'. Mabāhits Fù Ulūm al-Quran. ttp : Maktabah Wahbah, tth.

Sarakhsi (al). al-Mabsūt. Bairut: Dār al-Fikr, 2000.

Shihab, M. Quraish. Kaidah Tafsir, Syarat, Ketentuan dan Aturan yang Patut Anda Ketahui Dalam Memahami Ayat-Ayat al-Qur'an. Tanggerang : Lentera Hati, 2013.

. Wawasan al-Qur'an Tafsir Maudlu'I Atas Persoalan Pelbagai Umat. Bandung: Mizan, 2013.

Suyūti (al), Jalāl al-Din. Al-Dur Manthūr F̄̄ Tafsīr bi al-Ma'thūr. Bairut: Dār al-Fikr, 2003. . Al-Itqān Fi ulūm al-Quran. Bairut : Dar al-Fikr, 2008.

Suharso dan Ana Retnoningsih. Kamus Besar Bahasa Indonesia. Semarang: Widya Karya, 2012.

Syafi'i (al), Muhammad bin Idris. Ahkām al-Qur'an. Bairut: Dār al-Kutub al-'Ilmiyah, th.

Syahrur, Muahmmad. Prinsip dan Dasar Hermeneutika Hukum Islam Kontemporer. terj Sahiron Syamsuddin. Yogyakarta : ELSAQ Press, 2007.

Ṭaha, Mahmūd Muhammad. Risalah al-Tsaniyah fi al-Islām. ttp : tnp, tth. . Syari'ah Demokratik, terj. Nur Rachman. Surabaya : elSAD.

Zaya'i (al), Fakhr al-Dīn 'Uthmān bin'Al̄̄. Tabȳ̄n al-Haqāiq Sharh Kanz al-Daqāiq. Kairo: Dār al-Kutub al-Islām.

Zuhdi, M. Nurdin. "Tipologi Tafsir al-Qur'an Madzhab Indonesia". Tesis di UIN Sunan Kalijaga Yogyakarta, 2011.

http://www.bbc.com/indonesia/majalah/2016/06/160627 trensosial_burma_masjid diakses pada 5 Agustus 2016

http://www.kiblat.net/2016/01/08/ini-jumlah-korban-agresi-israel-di-palestina-selama-2015/ diakses pada 5 Agustus 2016 